\title{
SNP Discrimination by Tolane-Modified Peptide Nucleic Acids: Application for the Detection of Drug Resistance in Pathogens
}

\author{
Kenji Takagi ${ }^{1}$, Tenko Hayashi ${ }^{1}$, Shinjiro Sawada ${ }^{1}$, Miku Okazaki $^{1}$, Sakiko Hori ${ }^{1}$, \\ Katsuya Ogata ${ }^{1}$, Nobuo Kato ${ }^{1}$, Yasuhito Ebara ${ }^{2, *(1)}$ and Kunihiro Kaihatsu 1,2,* \\ 1 Department of Organic Fine Chemicals, The Institute of Scientific and Industrial Research, Osaka University, \\ 8-1 Mihogaoka, Ibaraki, Osaka 567-0047, Japan; takagi33@sanken.osaka-u.ac.jp (K.T.); \\ haya33@sanken.osaka-u.ac.jp (T.H.); sinistergale@yahoo.co.jp (S.S.); okazaki33@sanken.osaka-u.ac.jp (M.O.); \\ hori_s@visgene.com (S.H.); ogata-k@visgene.com (K.O.); kato-n@sanken.oska-u.ac.jp (N.K.) \\ 2 Graduate School of Human Development and Environment, Kobe University, 3-11 Tsurukabuto, Kobe, \\ Hyogo 657-8501, Japan \\ * Correspondence: ebara@kobe-u.ac.jp (Y.E.); kunihiro@sanken.osaka-u.ac.jp (K.K.); \\ Tel.: +81-78-803-7759 (K.K.)
}

Received: 7 January 2020; Accepted: 7 February 2020; Published: 11 February 2020

\begin{abstract}
During the treatment of viral or bacterial infections, it is important to evaluate any resistance to the therapeutic agents used. An amino acid substitution arising from a single base mutation in a particular gene often causes drug resistance in pathogens. Therefore, molecular tools that discriminate a single base mismatch in the target sequence are required for achieving therapeutic success. Here, we synthesized peptide nucleic acids (PNAs) derivatized with tolane via an amide linkage at the $\mathrm{N}$-terminus and succeeded in improving the sequence specificity, even with a mismatched base pair located near the terminal region of the duplex. We assessed the sequence specificities of the tolane-PNAs for single-strand DNA and RNA by UV-melting temperature analysis, thermodynamic analysis, an in silico conformational search, and a gel mobility shift assay. As a result, all of the PNA-tolane derivatives stabilized duplex formation to the matched target sequence without inducing mismatch target binding. Among the different PNA-tolane derivatives, PNA that was modified with a naphthyl-type tolane could efficiently discriminate a mismatched base pair and be utilized for the detection of resistance to neuraminidase inhibitors of the influenza A/H1N1 virus. Therefore, our molecular tool can be used to discriminate single nucleotide polymorphisms that are related to drug resistance in pathogens.
\end{abstract}

Keywords: peptide nucleic acid; tolane; single nucleotide polymorphism; influenza virus; drug resistance

\section{Introduction}

A single nucleotide polymorphism (SNP), as a variation at a single position in a gene sequence among individuals [1], within viral genes often confers drug resistance to the pathogen, such as HIV-1 drug resistance [2] or oseltamivir-resistant influenza virus [3]. Therefore, the sequence-specific detection of SNPs in target genes while using oligonucleotides is a key technology for detecting pathogens and disease-related genes. The accuracy and sensitivity of diagnosis relies on the chemical properties of the oligonucleotides that were used for detection. Thus, various types of chemically modified nucleic acids have been developed to improve the binding affinity and sequence specificity. Peptide nucleic acids (PNAs) are DNA mimics in which the phosphate backbone has been replaced by a neutral amide backbone composed of $N$-(2-aminoethyl)glycine linkages [4]. The advantages of 
PNAs are their high binding affinity [5-7], good mismatch discrimination [8], nuclease and protease resistance [9], and low affinity for proteins [10].

Up to now, PNAs have been used to detect single nucleotide polymorphisms (SNPs) through a combination with various types of other technologies. Ross et al. have utilized PNAs to detect SNPs in target genes while using matrix-assisted laser desorption/ionization time-of-flight mass spectrometry (MALDI-TOFMS) of PCR products. This ability to detect SNPs can be achieved, because PNAs can form stable complexes with their target genes under low salt conditions [11]. In order to perform the simultaneous detection of multiple SNP sites in dsDNA by MALDI-TOFMS, Ren et al. mixed multiple PNAs and dsDNA and treated them first with exonuclease III and then with nuclease S1 to produce PNA/ssDNA fragments, including the SNP sites in situ. They succeeded in discriminating between various apolipoprotein E genotypes in patients while using dsDNAs that were obtained by PCR [12]. Boontha et al. developed a new ion-exchange capture technique for SNP detection using a pyrrolidinyl PNA probe. The complementary PNA/DNA hybrid is selectively captured by the anion exchanger in the presence of noncomplementary or unhybridized PNA, allowing for the direct detection of the hybridization event on the anion exchanger by MALDI-TOFMS. The accuracy of MALDI-TOFMS, in conjunction with the high specificity of PNA hybridization, offers promise for development into a multiplexed, high-throughput screening technique [13].

Gaylord et al., developed a method for the fluorescence-based detection of SNPs while using PNA probes conjugated with an optically amplifying conjugated polymer poly[(9,9-bis ( $6^{\prime}-N, N, N$-trimethylammoniumhexylbromide) fluorene)-co-phenylene], and S1 nuclease. Recognition is accomplished by the sequence-specific hybridization between the uncharged, fluorescein-labeled, PNA probe, and the DNA sequence of interest. After subsequent treatment with S1 nuclease, the cationic polymer electrostatically only associates with the remaining anionic PNA/DNA duplex, leading to the sensitized fluorescence emission of the labeled PNA probe via FRET from the cationic polymer [14]. They succeeded in detecting a known point mutation that had been implicated in a dominant neurodegenerative dementia known as frontotemporal dementia with Parkinsonism linked to chromosome 17 (FTDP-17), which has clinical and molecular similarities to Alzheimer's disease.

The fluorescence-based detection of SNPs is a simple, rapid, and robust technology. Rockenbauer et al. reported a new method that combined allele-specific hybridization, PNA technology, and detection while using flow cytometry. These authors described a fully functional two-bead genotyping system based on PNA capture and flow cytometric detection that they used for the accurate and fast re-genotyping of a Danish basal cell carcinoma cohort [15]. Bethge et al. synthesized forced intercalation probes (FIT-probes) that contained an intercalating cyanine dye, such as oxazole yellow (YO), which serves as a replacement for a canonical nucleobase. The YO in the FIT probes responds to adjacent base mismatches through the attenuation of fluorescence intensity under conditions where both matched and mismatched target DNAs are bound. The YO-PNA is capable of signaling the presence of fully complementary DNA by providing an up to 20-fold enhancement in fluorescence. Single base mismatches cause a significant attenuation of YO fluorescence [16]. Socher et al. also employed a thiazole orange (TO) modified FIT-PNA molecule to monitor SNPs in a target gene. They found that the use of D-ornithine rather than aminoethylglycine as the PNA backbone increased the intensity of the fluorescence emitted by matched probe-target duplexes, while the specificity of fluorescence under non-stringent conditions was also increased. The utility of these ornithine-containing FIT probes was demonstrated in a real-time PCR analysis providing a linear measurement range over at least seven orders of magnitude [17]. Ditmangklo et al. synthesized novel alkyne-modified styryl dyes for conjugation with pyrrolidinyl peptide nucleic acid (acpcPNA) while using click chemistry to detect the presence of structural defects, including mismatched, abasic, and base-inserted DNA targets. The largest increase in the fluorescence quantum yield (up to 14.5-fold) of styryl-dye-labelled acpcPNA was achieved with DNA carrying base insertions [18]. 
Kam et al. succeeded in discriminating SNPs in the KRAS oncogene in cultured cells while using two types of molecular beacons (MBs) based on either phosphothioated DNA (PS-DNA-MB) or peptide nucleic acid (TO-PNA-MB, where TO = thiazole orange). Cell transfection of TO-PNA-MB with the aid of PEI resulted in fluorescence in cells expressing the fully complementary RNA transcript (Panc-1), but undetectable fluorescence in cells expressing the K-ras mRNA that had a single mismatch to the TO-PNA-MB (HT29). In contrast, PS-DNA-MB showed no fluorescence in all the cell lines that were tested post PEI transfection [19]. Further, Kolevzon et al. synthesized a PNA bis-quinoline that was capable of detecting mutant K-ras mRNAs in cultured cells by monitoring far-red emission [20].

As mentioned above, PNA is a powerful tool that can be used to discriminate SNPs when used in combination with a mass spectrometer, PCR, or a fluorescence detector. The usefulness of PNA will be further amplified if it could be used for the rapid diagnosis of viral and bacterial drug-resistance in clinical specimens. This could be achieved by improving the hybridization properties of the PNA, eliminating the need for any expensive equipment. We recently reported that the hybridization property of a PNA could be enhanced by azobenzene modification at the $N$-terminus [21]. We also attached intercalators containing larger pi-conjugated systems, such as acridine and pyrene to the $N$-terminus of PNA via amide linkages. However, these modifications increased binding not only to the matched DNA, but also to the mismatched DNA (data not shown). Dogan et al. [22] reported that modification by stilbene, an orthogonal molecule, at the 5'-terminus of the DNA, also enhanced the binding affinity for matched DNA/DNA duplex formation, without increasing the formation of mismatched duplexes. These reports inspired us to explore modification of the $N$-terminus end of PNA with a more rigid and orthogonal molecule when compared to stilbene, which could increase the binding affinity and sequence specificity of PNA to DNA and RNA.

In this study, we designed and synthesized various types of intercalators utilizing a diphenylachetylene(tolane) backbone and attached them to the N-terminus of the PNA via amide linkage. The binding affinities and sequence specificities of these PNA derivatives for DNA or RNA were assessed by a UV-melting temperature analysis and a gel mobility shift assay. We also developed a novel type of rapid diagnostic test kit for discriminates SNP relating neuraminidase inhibitor-resistant virus of the seasonal influenza virus.

\section{Results and Discussion}

\subsection{Design and Synthesis of PNA and Tolane-PNA}

The typical duplex structure of PNA/DNA has been reported in the Protein Data Bank (PDB:1PDT). We introduced a diphenylacetylene (tolane) derivative to the $N$-terminal of PNA via an amide linkage and performed an in silico conformational search while using MacroModel to design a chemically modified PNA that can form a stable stacking conformation with the terminal base pairs (Figure 1). As can be seen in Figure 1, the tolane molecule (Figure 2, tolane1) appeared to form a stacking interaction with a neighboring base pair in the terminal region of the PNA/DNA duplex. We reasoned that the optimization of the linker length in tolane might further enhance the stacking conformation in the PNA/DNA duplex. Accordingly, we synthesized a series of tolane molecules that had different linker lengths or pi-conjugation systems (Figure 2). These were introduced to the N-terminal region of a 12-mer poly-pyrimidine PNA (PNA0) that is known to be sensitive to mismatches and it is unable to form a triplex with the target DNA (Table 1). The lysine at the C-terminus was introduced to increase the water solubility of the PNA. 


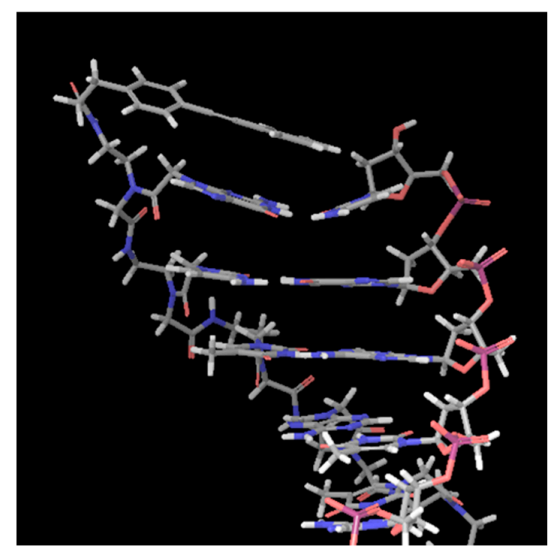

Figure 1. Conformational search of the tolane1 modified Peptide nucleic acid (PNA)/DNA duplex. The original PNA/DNA duplex structure was obtained from the Protein Data Bank (PDB:1PDT). The conformational search was performed while using the force field OPLS2005 model in MacroModel.

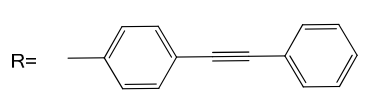<smiles>[R]CCC(=O)O</smiles><smiles>[R]CC(=O)O</smiles><smiles>[R]CCCC(=O)O</smiles><smiles>[R]CCCCC(=O)O</smiles><smiles>[R]CCCCCC(=O)O</smiles><smiles>[R]CCOCC(=O)O</smiles><smiles>[R]COCCC(=O)O</smiles><smiles>[R]CC(=O)NCC(=O)O</smiles><smiles>[R][Y9][14CH2]COCC(=O)O</smiles><smiles>[R]c1ccc(C#Cc2ccc3ccccc3c2)cc1</smiles><smiles>[R]c1ccc(C#Cc2ccc3ccc4c5c3c2CC=C5CC=C4)cc1</smiles><smiles>[R]c1ccc(C#Cc2ccc(OC)cc2)cc1</smiles><smiles>[R]c1ccc(C#Cc2ccc(C#N)cc2)cc1</smiles><smiles>NCCCCC(N)C(N)=O</smiles>

C-terminus

\section{Tolane1-PNA}

Figure 2. Chemical structure of the tolane derivatives. 1-5) tolanes containing different alkyl linker lengths, 6-8) tolanes containing either ether or amide linkages, 9-12) tolanes containing different pi-conjugation systems. Tolane1-PNA) Schematic diagram of tolane1 modified PNA. A lysine residue was introduced to the C-terminus of the PNA molecule to increase water solubility. Tolane1 was attached to the $\mathrm{N}$-terminal amino group through an amide linkage. 
Table 1. PNA and DNA sequences used for studying the effect of tolane molecules on UV-melting temperature analysis.

\begin{tabular}{cccc}
\hline \multirow{2}{*}{ Name } & PNA (N-C)/DNA or RNA (5' -3' $\left.^{\prime}\right)$ & \multicolumn{2}{c}{ Mass } \\
\cline { 3 - 4 } & & Calculated & Found \\
\hline PNA0 & TTCCCTCCTCTA-Lys & 3258.38 & 3261.74 \\
PNA1 & Tolane1-TTCCCTCCTCTA-Lys & 3490.67 & 3495.84 \\
PNA2 & Tolane2-TTCCCTCCTCTA-Lys & 3476.65 & 3482.33 \\
PNA3 & Tolane3-TTCCCTCCTCTA-Lys & 3504.70 & 3508.71 \\
PNA4 & Tolane4-TTCCCTCCTCTA-Lys & 3518.73 & 3519.78 \\
PNA5 & Tolane5-TTCCCTCCTCTA-Lys & 3532.76 & 3536.00 \\
PNA6 & Tolane6-TTCCCTCCTCTA-Lys & 3520.70 & 3520.79 \\
PNA7 & Tolane7-TTCCCTCCTCTA-Lys & 3520.70 & 3521.16 \\
PNA8 & Tolane8-TTCCCTCCTCTA-Lys & 3533.72 & 3534.27 \\
PNA9 & Tolane9-TTCCCTCCTCTA-Lys & 3570.76 & 3570.68 \\
PNA10 & Tolane10-TTCCCTCCTCTA-Lys & 3644.85 & 3642.05 \\
PNA11 & Tolane11-TTCCCTCCTCTA-Lys & 3550.73 & 3552.13 \\
PNA12 & Tolane12-TTCCCTCCTCTA-Lys & 3545.71 & 3546.78 \\
DNA1 & ATGTCCTAGAGGAGGGAATAA & - & - \\
DNA2 & ATGTCCTAGAGGAGGGCATAA & - & - \\
\hline
\end{tabular}

Lys: lysine, Underlined: mismatch base. Calculated: expected molecular weight, Found: molecular weight identified by MALDI-TOFMS.

\subsection{The Effect of Linker Structures in the Tolane-PNAs on Duplex Stability with Single Strand DNA}

The thermal stabilities of the tolane-PNA/DNA duplexes were used to assess the effects of the different tolane derivatives on duplex stability. We measured the melting temperature (Tm) of PNA0-12 with a single stranded DNA (DNA1). The Tm of the matched PNA0/DNA1 was $56.5^{\circ} \mathrm{C}$, while that of the mismatched PNA0/DNA2 was $48.6^{\circ} \mathrm{C}$, thus representing a difference of $7.9^{\circ} \mathrm{C}$.

PNAs 1-5 represent molecules with different lengths of the alkyl chain spacer that lies between the PNA and the tolane moiety. The Tms of their duplexes with DNA1 increased in an alkyl length-dependent manner until the tolane linker was pentanoic acid (Table 2. PNA4, $61.7{ }^{\circ} \mathrm{C}$ ). The PNA5/DNA1 duplex, which contained a hexanoic acid linker, had a lower Tm than the PNA4/DNA1 duplex (Table 2. $59.6{ }^{\circ} \mathrm{C}$ ). Pentanoic acid seemed to be an optimal linker length for tolane-PNA conjugates based on these data. Interestingly, the Tms of the PNA0-5/DNA2 mismatched duplexes did not increase with alkyl chain length (Table $2 . \mathrm{Tm}=48.1-48.8^{\circ} \mathrm{C}$ ). Among PNA0-5, PNA4 gave the largest $\Delta \operatorname{Tm}\left(+13.0^{\circ} \mathrm{C}\right)$, which was $5.1^{\circ} \mathrm{C}$ larger than that of PNA0 $\left(\Delta \operatorname{Tm}=+7.9^{\circ} \mathrm{C}\right)$. Tolane4 in PNA4 could efficiently associate with adjacent base pairs in the matched PNA/DNA duplex and it also stabilized the duplex formation.

We further investigated the effect of the chemical structure of the tolane linkers on PNA/DNA duplex formation. We elected to use a tolane linker length, which was the same as hexanoic acid; however, we substituted the aliphatic linkers with two more flexible and hydrophilic ether linkers (Figure 2, tolane6-7) or a more rigid amide linkage (Figure 2. tolane8). The two different types of ether linkers and the amide linker were introduced to the N-terminus of PNA, as shown in Table 1 (PNA6-8). PNA6 and PNA7 both contain flexible ether linkers that increased duplex stability with DNA1 relative to PNA4 (Table 2, PNA6/DNA1 Tm $=63.0^{\circ} \mathrm{C}$, PNA7/DNA1 Tm $=62.2^{\circ} \mathrm{C}$ ). In contrast, PNA8 contains a more rigid amide linker that had a slightly lower Tm (Table 2, PNA8/DNA1 Tm $=60.9^{\circ} \mathrm{C}$ ) when compared to PNA4. We performed a conformational search of tolane6 and tolane8 in the PNA/DNA duplex (PDB:1PDT) by an in silico conformational search while using MacroModel ${ }^{\circledR}$ to understand the mode of binding of tolane molecules within the PNA/DNA duplex. As a result, the flexible ether linker of tolane 6 efficiently formed stacking conformation with the terminal base pairs, while the rigid amide linked tolane8 did not (Figure 3). 
Table 2. Thermal stability of PNA/DNA and tolane-PNA/DNA duplexes.

\begin{tabular}{cccc}
\hline \multirow{3}{*}{ PNA } & \multicolumn{3}{c}{$\left.\operatorname{Tm}^{\circ}{ }^{\circ} \mathbf{C}\right)$} \\
\cline { 2 - 4 } & Match $^{\mathbf{1}}$ & Mismatch $^{2}$ & $\Delta$ Tm $^{3}$ \\
\hline 0 & $56.5 \pm 0.9$ & $48.6 \pm 0.9$ & 7.9 \\
1 & $60.8 \pm 0.6$ & $48.8 \pm 0.7$ & 12.0 \\
2 & $59.3 \pm 0.9$ & $48.5 \pm 0.9$ & 10.8 \\
3 & $60.1 \pm 0.1$ & $48.1 \pm 0.7$ & 12.0 \\
4 & $61.7 \pm 0.9$ & $48.7 \pm 0.8$ & 13.0 \\
5 & $59.6 \pm 0.2$ & $48.4 \pm 0.3$ & 11.2 \\
6 & $63.0 \pm 0.6$ & $48.5 \pm 0.9$ & 14.5 \\
7 & $62.2 \pm 0.3$ & $48.8 \pm 0.6$ & 13.4 \\
8 & $60.9 \pm 0.3$ & $48.7 \pm 0.4$ & 12.2 \\
9 & $64.8 \pm 0.6$ & $48.3 \pm 0.9$ & 16.5 \\
10 & $60.7 \pm 1.2{ }^{4}$ & $48.6 \pm 0.3$ & 12.1 \\
11 & $60.9 \pm 0.5$ & $48.9 \pm 0.7$ & 12.0 \\
12 & $63.3 \pm 0.7$ & $49.2 \pm 0.2$ & 14.1 \\
\hline
\end{tabular}

${ }^{1}$ Mean Tm \pm SD $(n=3), \overline{T m}$ between each PNA and DNA1, ${ }^{2}$ Mean Tm \pm SD $(n=3)$, Tm between each PNA and DNA2. ${ }^{3} \Delta \mathrm{Tm}=\mathrm{Tm}$ (matched) $-\mathrm{Tm}$ (mismatched). ${ }^{4} 20 \%$ methanol was added to dissolve the pyrene-PNA in $20 \mathrm{mM}$ phosphate buffer ( $\mathrm{pH}$ 7.4).

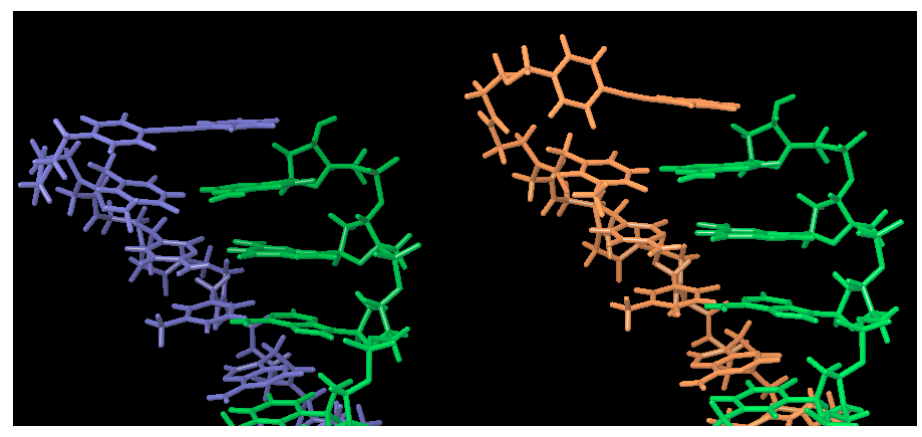

Figure 3. Molecular docking simulation of the tolane-PNA/DNA duplex conformation. Left: tolane6 in PNA forms a favorable stacking conformation with the terminal base pair of the PNA/DNA duplex via its flexible ether linker. Right: tolane8 in PNA forms a stacking interaction with the DNA bases, but not with the terminal base of the PNA due to the rigidity of the amide backbone. The PNA/DNA duplex structures were obtained as 1PDT from the PDB data bank and the conformational search was performed using the force field OPLS2005 model and MacroModel. Green; DNA, Blue; PNA conjugated with tolane6, Orange; PNA conjugated with tolane8.

We performed a conformational search using the same procedures to understand the different effects of tolane6 and tolane7. As a result, tolane6 formed a stable stacking interaction with the adjacent PNA/DNA base pair, while tolane7 could only form a stacking interaction with the DNA bases (Figure 4). Regardless of the flexibility of the linker, PNA 6 and 7 did not show an increase in the Tm for the duplex with mismatched DNA2 (Table 2). From these results, we chose the ethoxyacetate linker for the further optimization of the tolane molecules. 


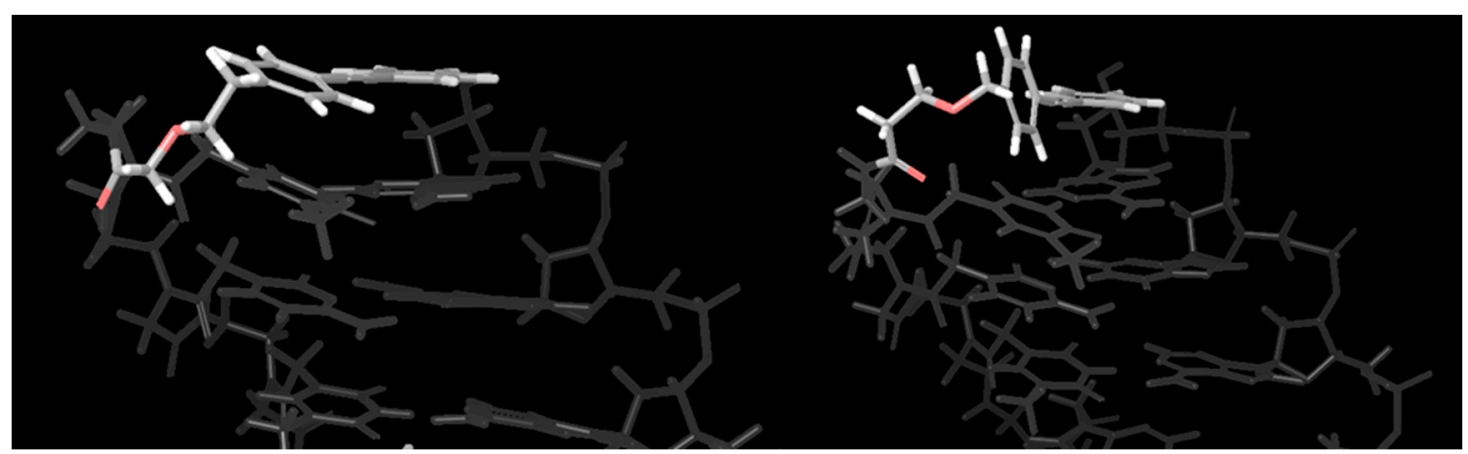

Figure 4. Molecular docking simulation of the tolane-PNA/DNA duplex conformation. Left: tolane6 formed a favorable stacking conformation with the terminal base pair of the PNA/DNA duplex via its flexible ether linker. Right: tolane7 was unable to form a stacking interaction with the N-terminal base pair due to the rigidity of the amide linker. The PNA/DNA duplex structures were obtained as 1PDT from the PDB data bank and the conformational search was performed with the OPLS2005 force field and gradient termination at $0.001 \mathrm{~kJ} / \mathrm{mol}-\AA$ (MacroModel, 2010).

\subsection{Modification of the Tolane Structure to Enhance the Stacking Interaction with the PNA/DNA Duplex}

In the previous section, the optimization process showed that the ethoxyacetic acid linker (tolane6) was the best candidate among tolane1-8. We next modified the structure of the tolane backbone to enhance the stacking interaction with the terminal base pairs of the PNA/DNA. According to our in silico conformational search that is shown in Figure 5, an extended pi-conjugate system might increase the stacking interaction with the terminal base pair of PNA/DNA (Figure 5. Top view of the tolane-PNA/DNA duplex. Red: tolane6, White: terminal base pair).

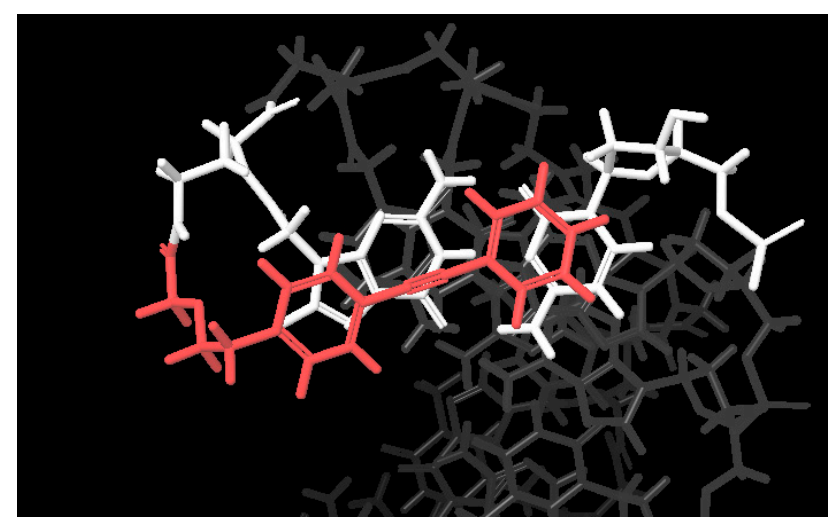

Figure 5. Conformational search of tolane6-PNA/DNA using MacroModel. Force Field; OPLS2005, Solvent: water, Red; tolane. White; terminal base pairs.

Based on these data, we synthesized tolane 9 and 10, which had extended pi-conjugated systems in their terminal phenyl group and tolane11 and $\mathbf{1 2}$ that had an electron donor and an acceptor group, respectively. Each compound was attached to the amino group at the N-terminus of the PNA and the resulting DNA binding affinities were assessed by a UV-melting temperature analysis (Table 2). As a result, tolane9, which contains a naphthyl group, increased the duplex stability with DNA1 (Table 2, $\mathrm{Tm}=64.8^{\circ} \mathrm{C}$ ) and the thermal stability was found to be higher than that of tolane6 $\left(\mathrm{Tm}=63.0^{\circ} \mathrm{C}\right)$. On the other hand, tolane 9 had almost no effect on the thermal stability of the mismatched PNA9/DNA2 duplex (Table $2, \mathrm{Tm}=48.3^{\circ} \mathrm{C}$ ). As PNA 10 possesses a pyrene group, it has poor solubility in aqueous solution. Therefore, we used $20 \%$ methanol in a phosphate buffered solution to measure the Tm of DNA1. As a result, the pyrene containing tolane 10, which has an enhanced pi-conjugated system and had a lower $\mathrm{Tm}$ when compared to tolane 9 (Table 2, $\mathrm{Tm}=60.7^{\circ} \mathrm{C}$ ). Although the pi-conjugated system in tolane $\mathbf{1 0}$ is larger than that tolane $\mathbf{9}$, the poor water solubility of tolane10 made it unsuitable 
for forming a stacking interaction with the neighboring base pairs in the PNA 10/DNA1 duplex when in an aqueous solution.

We next examined the effect of functional groups at the para-position in tolane on the thermal stability of the PNA/DNA duplex. PNA11, which has an electron donating methoxy group in tolane11, had a lower $\mathrm{Tm}$ (Table 2, $\mathrm{Tm}=60.9^{\circ} \mathrm{C}$ ) when compared to PNA7. The structural bulkiness of the methoxy group in tolane11 might cause steric hindrance with the neighboring base pairs in PNA12/DNA1 and prevent the stacking interaction. PNA13, which has an electron withdrawing cyano group in tolane12, had nearly the same $\mathrm{Tm}$ (Table $2, \mathrm{Tm}=63.3^{\circ} \mathrm{C}$ ) as PNA6. These data indicate that the electron density of the tolane molecule does not affect the stacking interaction with the terminal base pair of the tolane-PNA/DNA. Overall, the tolane derivatives did not stabilize the mismatch duplex formation of the tolane-PNA/DNA, regardless of the modified functional groups. Based on the $\Delta \mathrm{Tm}$ $\left(16.5^{\circ} \mathrm{C}\right)$ in Table 2, PNA9, which is a naphthyl type tolane (tolane 9), had the best sequence specificity.

\subsection{Analysis of the Duplex Conformation of the Tolane-PNA/DNA Duplexes by Fluorescence Spectroscopy}

We analyzed the fluorescence spectra of PNA9 in the absence or presence of matched DNA1 or mismatched DNA2 to understand the mode of action of tolane9 in the PNA/DNA duplex. PNA9 was dissolved in $20 \mathrm{mM}$ phosphate buffer ( $\mathrm{pH}$ 7.4) at a concentration of $4 \mu \mathrm{M}$ at $25^{\circ} \mathrm{C}$. The excitation wavelength of tolane 9 in PNA 9 was found to be $323 \mathrm{~nm}$, while the emission wavelength was found to be $384 \mathrm{~nm}$ (Figure 6, fluorescence intensity: 402.24). The fluorescence intensity was drastically quenched to 151.94 when PNA9 was mixed with matched DNA1 at a 1:1 molar ratio (Figure 6). This is likely to be as the result of the stacking interaction of tolane9 with the neighboring base pairs in PNA9/DNA1. On the other hand, when PNA9 was mixed with mismatched DNA2 at a 1:1 molar ratio, the fluorescence intensity was decreased by about half relative to DNA1 (Figure 6, fluorescence intensity: 271.33). These results indicated that tolane 9 could form an efficient stable stacking conformation with matched DNA1. When a penultimate base pair of the PNA/DNA was mismatched, tolane 9 did not form a stable stacking conformation with an adjacent base pair due to the fraying of the base pairs in the terminal region.

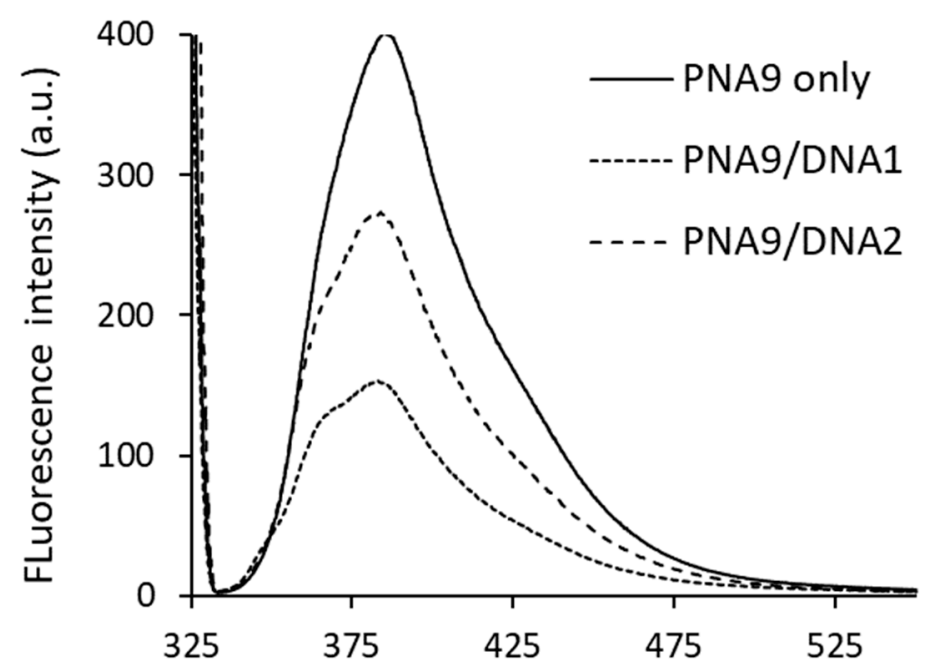

Figure 6. The fluorescence spectra of PNA9 (solid), PNA9/DNA1 (dashed-dotted line), and PNA9/DNA2 (dashed line) were measured in $20 \mathrm{mM}$ sodium phosphate buffer ( $\mathrm{pH} \mathrm{7.4).} \mathrm{Conditions:} \mathrm{PNA,}$ $\mathrm{DNA}=4 \mu \mathrm{M}$, Excitation $=323 \mathrm{~nm}$, Emission $=384 \mathrm{~nm}$, Temperature $=25^{\circ} \mathrm{C}$.

\subsection{Thermodynamic Study of the PNA/DNA and Tolane-PNA/DNA Duplexes}

We analyzed the thermodynamic parameters of PNA0 and PNA9 with matched DNA1 and mismatched DNA2 to study the binding behavior of tolane9. The Tm values of the duplex varied depending on their total concentration. Thus, we measured the Tm of each duplex and plotted 1/Tm on the vertical axis and $\ln (\mathrm{Ct} / 4)$ on the horizontal axis, as shown in Figure 7 . The enthalpy $(\Delta \mathrm{H})$ was 
calculated from the slope of the approximate line obtained, and the entropy $(\Delta S)$ was calculated from the intercept, as indicated in Equation (1) below. Figure 7 shows the actual plots and approximate straight lines. $\Delta \mathrm{G}$ was calculated based on Equation (2).

$$
\begin{gathered}
1 / \mathrm{Tm}=(\mathrm{R} / \Delta \mathrm{H}) \ln (\mathrm{Ct} / 4)+\Delta \mathrm{S} / \Delta \mathrm{H} \\
\Delta \mathrm{G}=\Delta \mathrm{H}-\mathrm{T} \Delta \mathrm{S}
\end{gathered}
$$

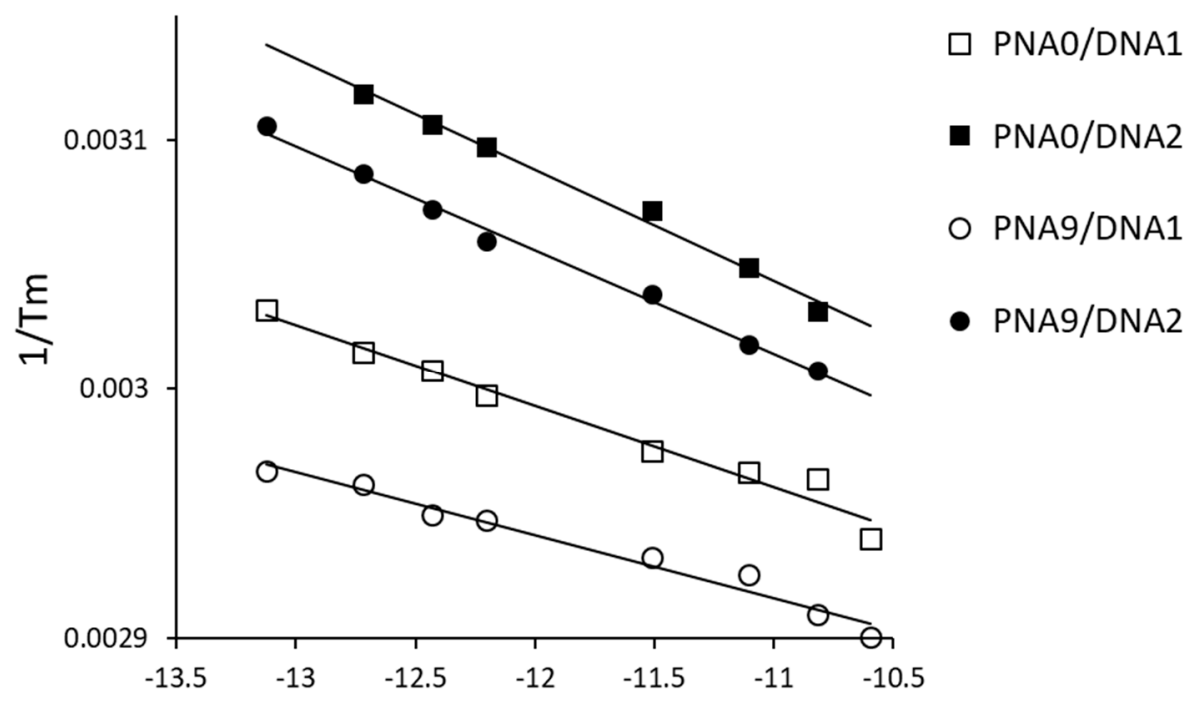

Figure 7. Tm plot of the PNA/DNA and tolane-PNA/DNA duplexes at different concentrations in $20 \mathrm{mM}$ phosphate buffer ( $\mathrm{pH}$ 7.4). The $\mathrm{R} / \Delta \mathrm{H}$ values were calculated from the slope of each approximate straight line. The $\Delta \mathrm{S} / \Delta \mathrm{H}$ values were calculated from the estimated intercept on the $1 / \mathrm{Tm}$ line as $\ln (\mathrm{Ct} / 4)$ approached zero.

We obtained the R/ $\Delta \mathrm{H}$ for PNA0/DNA1, PNA0/DNA2, PNA9/DNA1, and PNA9/DNA2, which was $3.25 \times 10^{-5}, 4.47 \times 10^{-5}, 2.52 \times 10^{-5}$, and $4.18 \times 10^{-5}\left(\mathrm{~K}^{-1}\right)$, respectively, according to the approximate straight line in Figure 7 . In addition, the $\Delta \mathrm{S} / \Delta \mathrm{H}$ ratio for PNA0/DNA1, PNA0/DNA2, PNA9/DNA1, and PNA9/DNA2 was calculated as $2.60 \times 10^{-6}, 2.55 \times 10^{-6}, 2.64 \times 10^{-6}$, and $2.55 \times 10^{-6}\left(\mathrm{~K}^{-1}\right)$, respectively. The heat capacity should be negligible. The gas constant $(\mathrm{R})$ was $0.00199(\mathrm{kcal} /(\mathrm{mol} \cdot \mathrm{K}))$. These data were used for calculating the $\Delta \mathrm{H}, \Delta \mathrm{S}$, and $\Delta \mathrm{G}$ values, according to Equations (1) and (2), and they are summarized in Table 3.

The $\Delta \mathrm{G}$ values in Table 3 showed good correlations with the Tm values. When comparing the $\Delta \mathrm{H}$ of the matched PNA/DNA duplex, PNA9 $(-79.1 \mathrm{kcal} / \mathrm{mol})$ had a smaller value than PNA0 $(-61.8 \mathrm{kcal} / \mathrm{mol})$, which indicates that tolane 9 forms a stacking interaction with the neighboring base pairs by intermolecular bindings, such as pi-pi stacking interactions and hydrogen bonds. When comparing the $\Delta \mathrm{S}$ of the matched PNA/DNA, PNA9 $(-208.8 \mathrm{cal} / \mathrm{mol} \cdot \mathrm{K})$ had a smaller value than PNA0 $(-159.5 \mathrm{cal} / \mathrm{mol} \cdot \mathrm{K})$, which indicates that the stacking interaction of tolane 9 impairs the structural flexibility at the terminal region of the PNA/DNA duplex. However, the enthalpy contribution was relatively bigger than the loss of entropy, so, as a result, the free energy of PNA9 $(-16.9 \mathrm{kcal} / \mathrm{mol})$ was lower than PNA0 $(-13.7 \mathrm{kcal} / \mathrm{mol})$ and formed a stable duplex. Looking at the thermodynamic parameters of the mismatched duplexes in Table 3 revealed that PNA0 and PNA9 had almost the same values. This suggested that tolane9 has negligible interaction with PNA/DNA duplex when the mismatched base is located at the second base position from the terminus. This sequence specificity was caused by the structural rigidity of the tolane, since the diphenylacetylene backbone can adopt a stacking conformation only when the terminal base pair forms a matched duplex. 
Table 3. Thermodynamic parameters of the PNA/DNA duplex.

\begin{tabular}{|c|c|c|c|c|}
\hline & $\begin{array}{l}\Delta \mathrm{G}^{\circ}(298 \mathrm{~K}) \\
(\mathrm{kcal} / \mathrm{mol})\end{array}$ & $\begin{array}{c}\Delta \mathrm{H}^{\circ} \\
\text { (kcal/mol) }\end{array}$ & $\begin{array}{r}\Delta S^{\circ}(298 \mathrm{~K}) \\
(\mathrm{cal} / \mathrm{mol} \cdot \mathrm{K})\end{array}$ & $\begin{array}{l}{ }^{\circ} \mathrm{Cm} \\
\mathrm{Cm}\end{array}$ \\
\hline PNA0/DNA1 & -13.7 & -61.8 & -159.5 & $56.6 \pm 0.9$ \\
\hline PNA9/DNA1 & -16.9 & -79.1 & -208.8 & $64.9 \pm 0.6$ \\
\hline PNA0/DNA2 & -10.7 & -44.6 & -113.7 & $49.4 \pm 0.9$ \\
\hline PNA9/DNA2 & -11.3 & -47.6 & -121.5 & $50.2 \pm 0.9$ \\
\hline
\end{tabular}

\subsection{Recognition of Single Base Mismatched DNA by Tolane 9}

We prepared DNA3-5, which had three single base mismatches at the first, second, and third bases from the $3^{\prime}$-terminus, respectively, to confirm that tolane 9 can discriminate a single base mismatch in its target DNA (Table 4). As summarized in Table 5, tolane9 in PNA9 slightly increased the Tm for the mismatched DNAs (DNA3: $+0.3-+2.5^{\circ} \mathrm{C}$, DNA4: $+0.8-2.6{ }^{\circ} \mathrm{C}$, DNA5: $+0.3-1.5^{\circ} \mathrm{C}$ ) compared to PNA0/DNA3-4. On the other hand, PNA9 increased the Tm for the matched DNA by approximately $8.3^{\circ} \mathrm{C}$. Therefore, its sequence specificity is improved, as shown in Figure 8 , as $\Delta \mathrm{Tm}[\Delta \mathrm{Tm}=\mathrm{Tm}$ (matched) - Tm (mismatched), maximum $\Delta \mathrm{Tm} ;+14.7^{\circ} \mathrm{C}$ (T/C mismatch with DNA4), minimum $\Delta \mathrm{Tm}$; $+4.8^{\circ} \mathrm{C}$ (T/G mismatch with DNA3)]. Although there are many other possible mismatch variations in the PNA/DNA duplex, we think that tolane 9 can improve the sequence specificity, regardless of the exact location of the mismatch.

Table 4. PNA and DNA sequences used to study single base mismatch discrimination. The underlined sequences in DNA3, 4, and 5 were the mismatched bases to both PNA0 and PNA9.

\begin{tabular}{|c|c|}
\hline & PNA (N-C)/DNA $\left(5^{\prime}-3^{\prime}\right)$ \\
\hline PNA0 & TTCССТССТCTA-Lys \\
\hline PNA9 & Tolane9-ТTСССТССТСТA-Lys \\
\hline DNA1 & ATGTCCTAGAGGAGGGAATAA \\
\hline DNA3-T & ATGTCCTAGAGGAGGGATTAA \\
\hline DNA3-G & ATGTCCTAGAGGAGGGAḠTAA \\
\hline DNA3-C & ATGTCCTAGAGGAGGGAC̄TAA \\
\hline DNA4-T & ATGTCCTAGAGGAGGGTATAA \\
\hline DNA4-G & 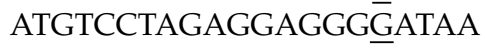 \\
\hline DNA4-C & ATGTCCTAGAGGAGGGC̄ATAA \\
\hline DNA5-T & ATGTCCTAGAGGAGGTĀATAA \\
\hline DNA5-A & ATGTCCTAGAGGAGG프AATAA \\
\hline DNA5-C & ATGTCCTAGAGGAGGㅡㅡAATAA \\
\hline
\end{tabular}

Table 5. UV-melting temperature analysis of PNA0 and PNA9 with DNA containing a single base mismatch at the first (DNA3), second (DNA4), and third (DNA5) base from the N-terminus of the PNA.

\begin{tabular}{|c|c|c|c|c|c|c|c|c|c|c|}
\hline \multirow{3}{*}{ PNA } & \multicolumn{10}{|c|}{$\operatorname{Tm}\left({ }^{\circ} \mathrm{C}\right)$} \\
\hline & \multirow{2}{*}{$\begin{array}{c}\text { Matched }^{1} \\
\text { DNA1 }\end{array}$} & \multicolumn{3}{|c|}{$\begin{array}{l}\text { Mismatched }^{1} \\
\text { DNA3 }\end{array}$} & \multicolumn{3}{|c|}{$\begin{array}{c}\text { Mismatched }^{1} \\
\text { DNA4 }\end{array}$} & \multicolumn{3}{|c|}{$\begin{array}{c}\text { Mismatched }^{1} \\
\text { DNA5 }\end{array}$} \\
\hline & & $\mathrm{T} / \mathrm{T}$ & $T / G$ & $\mathrm{~T} / \mathrm{C}$ & $T / T$ & $\mathrm{~T} / \mathrm{G}$ & $\mathrm{T} / \mathrm{C}$ & $\mathrm{C} / \mathrm{T}$ & C/A & $\mathrm{C} / \mathrm{C}$ \\
\hline PNA0 & $\begin{array}{c}56.6 \\
( \pm 0.9)\end{array}$ & $\begin{array}{c}57.0 \\
( \pm 0.4)\end{array}$ & $\begin{array}{c}57.7 \\
( \pm 0.3)\end{array}$ & $\begin{array}{c}53.0 \\
( \pm 0.9)\end{array}$ & $\begin{array}{c}56.7 \\
( \pm 1.9)\end{array}$ & $\begin{array}{c}56.6 \\
( \pm 1.2)\end{array}$ & $\begin{array}{c}49.6 \\
( \pm 0.9)\end{array}$ & $\begin{array}{c}54.0 \\
( \pm 0.8)\end{array}$ & $\begin{array}{c}53.7 \\
( \pm 0.7)\end{array}$ & $\begin{array}{c}52.5 \\
( \pm 1.1)\end{array}$ \\
\hline PNA9 & $\begin{array}{c}64.9 \\
( \pm 0.6)\end{array}$ & $\begin{array}{c}59.5 \\
( \pm 0.1)\end{array}$ & $\begin{array}{c}60.1 \\
( \pm 0.3)\end{array}$ & $\begin{array}{c}53.3 \\
( \pm 0.2)\end{array}$ & $\begin{array}{c}58.5 \\
( \pm 0.8)\end{array}$ & $\begin{array}{c}59.2 \\
( \pm 0.9)\end{array}$ & $\begin{array}{c}50.2 \\
( \pm 0.9)\end{array}$ & $\begin{array}{c}55.4 \\
( \pm 0.4)\end{array}$ & $\begin{array}{c}55.2 \\
( \pm 0.5)\end{array}$ & $\begin{array}{c}52.8 \\
( \pm 0.5)\end{array}$ \\
\hline
\end{tabular}

${ }^{1}$ Mean Tm \pm SD ( $\left.=3\right)$, PNA, DNA; $4 \mu$ M each in $20 \mathrm{mM}$ phosphate buffer (pH 7.4). 


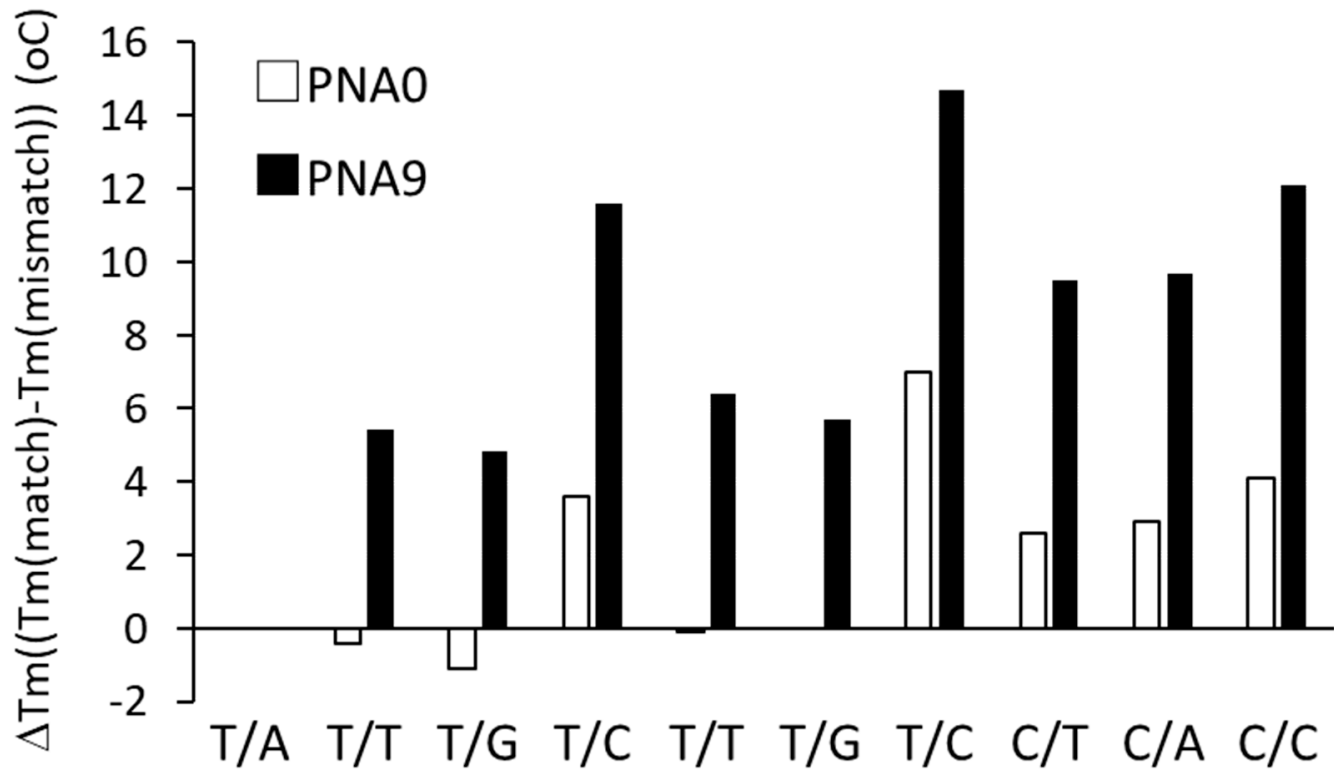

Figure 8. Measurement of Tm for PNA0/DNAs and PNA9/DNAs in $20 \mathrm{mM}$ phosphate buffer ( $\mathrm{pH}$ 7.4). $\Delta \mathrm{Tm}=\mathrm{Tm}$ (matched) $-\mathrm{Tm}$ (mismatched). DNA1 contains a complementary sequence to the PNAs. DNA3, DNA4, and DNA5 contain a mismatched base at the first, second, and third base from the N-terminus of the PNA.

2.7. Detection of Single Nucleotide Polymorphism (SNP) in a Neuraminidase Inhibitor-Resistant Influenza Virus by PNA13 and PNA14 Using a Gel Mobility Shift Assay

Neuraminidase inhibitors, such as Zanamivir and Oseltamivir, are antiviral medicines that are used to treat and prevent influenza virus infections. A SNP in the influenza A virus neuraminidase gene often causes drug-resistance to those neuraminidase inhibitors. Kawakami et al. identified the difference between a neuraminidase inhibitor-resistant influenza A viral gene (Yokohama/77/2008/H1N1, GenBank Accession number: AB465325) and a neuraminidase inhibitor-sensitive influenza A viral gene (Yokohama/1/2008/H1N1, GenBank Accession ID: AB519808) by direct sequencing of the PCR product of the neuraminidase gene during the previous swine influenza pandemic in 2008-2009 [23]. They found that nucleotide 823 (labeled from the $5^{\prime}$-terminus of the complementary viral RNA gene $((+)$ stand RNA), which causes a change from an adenine to a thymine, leads to the substitution of histidine to a tyrosine at amino acid 275 (H275Y). We synthesized PNA13 and PNA14 that are complementary to the viral gene in Influenza A/Yokohama/77/H1N1 to discriminate this SNP within the viral RNA((-) strand RNA). We attached a Lys-O-O-Lys-biotin linker (O; aminoethylethoxyacetate) to increase the water solubility and develop a nucleic acid chromatography method for the detection of a SNP associated with the neuraminidase inhibitor-resistance of influenza A/Yokohama/77/H1N1.

We first prepared DNAs that contained the sequences of influenza A/Yokohama/1/2008/H1N1 (Table 6, DNA6) and influenza A/Yokohama/77/2008/H1N1 (Table 6, DNA7) genes and performed a UV-melting temperature analysis. As a result, PNA14 had a Tm that was $5.8^{\circ} \mathrm{C}$ higher with the matched DNA7 $\left(\mathrm{Tm}=59.3^{\circ} \mathrm{C}\right)$ compared to PNA13/DNA7 $\left(\mathrm{Tm}=53.5^{\circ} \mathrm{C}\right)$. PNA14 had nearly the same Tm with mismatched DNA6 $\left(47.6^{\circ} \mathrm{C}\right)$ relative to PNA13/DNA6 $\left(\mathrm{Tm} 48.0^{\circ} \mathrm{C}\right)$. As a result, the modification of tolane 9 to PNA enhanced the $\Delta \mathrm{Tm}$ by $6.2^{\circ} \mathrm{C}$ (i.e., from $5.5^{\circ} \mathrm{C}$ (PNA13) to $11.7^{\circ} \mathrm{C}$ (PNA14)). These results indicated that tolane 9 only increases the binding affinity to the target sequence when the sequence is matched.

We also assessed the binding of PNA13 and PNA14 to RNA sequences that were derived from influenza A/Yokohama/1/H1N1 (Table 6, RNA1) and influenza A/Yokohama/77/H1N1 (Table 6, RNA2) neuraminidase genes. Each RNA consisted of 17 bases and the $5^{\prime}$-terminus was fluorescently labelled with Cy5 to allow for the visualization of the binding on a gel (Table 6, RNA1 and RNA2). PNA14 showed a higher $\mathrm{Tm}$ with the matched RNA2 (Table $7, \mathrm{Tm}=55.3^{\circ} \mathrm{C}$ ) when compared to PNA13/RNA2 
(Table 7, $\mathrm{Tm}=51.7^{\circ} \mathrm{C}$ ). On the other hand, PNA14 showed a significantly lower Tm with the mismatched RNA1 (Table 7, $\mathrm{Tm}=31.5^{\circ} \mathrm{C}$ ) as compared to PNA13/RNA1 (Table $7, \mathrm{Tm}=40.2{ }^{\circ} \mathrm{C}$ ). As a result, tolane9 improved the $\triangle \mathrm{Tm}$ of PNA by $23.8^{\circ} \mathrm{C}$ (Table 7 ), which is $12.3^{\circ} \mathrm{C}$ higher than PNA13 (Table 7 , $\Delta \mathrm{Tm}=11.5)$. We hypothesized that the lowered binding affinity of PNA14 to the mismatched RNA could be due to the hydrophobic property of tolane9, which prefers to form intramolecular interactions with neighboring PNA bases and avoids forming a mismatched duplex with the hydrophilic RNA that possesses $2^{\prime}$-hydroxyl groups. While using a conformational search that was conducted using MacroModel, as shown in Figure S1 (supplemental data), we compared the stability of the capped state of tolane-PNA/DNA, in which tolane forms a stacking interaction with neighboring base pair in the PNA/DNA duplex, and the backbone binding state of the tolane-PNA/DNA duplex, in which tolane is bound to the PNA backbone. The capped state is $2 \mathrm{kcal}$ more stable than the backbone binding state based on the $\Delta \mathrm{G}$ energy. The difference in $\Delta \mathrm{G}$ energy indicates that the relative abundance ratio of the capped state and backbone binding state within tolane-PNA/DNA is estimated to be 30:1.

Table 6. PNA13 and PNA14 used to detect a neuraminidase inhibitor-resistant gene in influenza virus A/Yokohama/77/H1N1 derived from a single nucleotide polymorphism (SNP) within the sequence. RNA1 contains the neuraminidase inhibitor-sensitive gene in influenza virus A/Yokohama/1/2008/H1N1, while RNA2 contains the neuraminidase inhibitor-resistant gene in influenza virus A/Yokohama/77/2008/H1N1. DNA6 and DNA7 contain the same sequence as RNA1 and RNA2, except that uracil bases were substituted with thymine bases.

\begin{tabular}{cccc}
\hline \multirow{2}{*}{ Name } & PNA $(\mathbf{N}-\mathrm{C}) / \mathbf{R N A}\left(\mathbf{5}^{\prime} \mathbf{- 3}^{\prime}\right)$ or DNA & \multicolumn{2}{c}{ Mass } \\
\cline { 3 - 4 } PNA13 & TTTTATTATGAG-Lys-O-O-Lys-biotin & 4062.35 & Found \\
PNA14 & Tolane9-TTTTATTATGAG-Lys-O-O-Lys-biotin & 4374.45 & 4374.45 \\
DNA6 & GCATTCCTCATAATAGAAATT & - & - \\
DNA7 & GCATTCCTCATAATAAAAATT & - & - \\
RNA1 & Cy5-GCAUUCCUCAUAAUAGAAAUU & - & - \\
RNA2 & Cy5-GCAUUCCUCAUAAUAAAAAUU & - & - \\
\hline
\end{tabular}

O: aminoethylethoxyacetate.

Table 7. UV-melting temperature analysis of PNA/DNA and PNA/RNA containing the neuraminidase inhibitor-resistant and neuraminidase-sensitive gene sequences.

\begin{tabular}{cccc}
\hline & $\begin{array}{c}\mathbf{T m}^{\mathbf{1}}\left({ }^{\circ} \mathbf{C}\right) \\
\text { With Sensitive Sequence }\end{array}$ & $\begin{array}{c}\mathbf{T m}^{\mathbf{2}}\left({ }^{\circ} \mathbf{C}\right) \\
\text { With Resistant Sequence }\end{array}$ & $\begin{array}{c}\Delta \mathbf{T m}\left(\mathbf{T m}^{\mathbf{2}}-\mathbf{T m}^{\mathbf{1}}\right) \\
\left({ }^{\circ} \mathbf{C}\right)\end{array}$ \\
\hline PNA13 & 48.0 (DNA6) & 53.5 (DNA7) & 5.5 \\
PNA14 & $47.6($ DNA6) & 59.3 (DNA7) & 11.7 \\
PNA13 & 40.2 (RNA1) & 51.7 (RNA2) & 11.5 \\
PNA14 & 31.5 (RNA1) & 55.3 (RNA2) & 23.8 \\
\hline
\end{tabular}

PNA/RNA; $4 \mu \mathrm{M}$ each in $10 \mathrm{mM}$ phosphate buffer and $1 \mathrm{mM}$ EDTA (pH 6.0).

We performed a gel mobility shift assay to study the effect of tolane 9 on the duplex formation between PNA and RNA. Cy5-labelled synthetic RNA oligonucleotides (RNA1 and RNA2 at a final concentration $100 \mathrm{nM}$ ) were incubated with three equivalents of the PNAs (PNA13 and PNA14 at a final concentration $300 \mathrm{nM}$ ) for $10 \mathrm{~min}$ in $10 \mathrm{mM}$ sodium phosphate buffer and $1 \mathrm{mM}$ EDTA (pH 6.0) at $25^{\circ} \mathrm{C}, 40^{\circ} \mathrm{C}$, and $55^{\circ} \mathrm{C}$. PNA13 bound to both the mismatched RNA1 and the matched RNA2 and gave band shifts on the gel, regardless of the incubation temperature, as shown in Figure 9. PNA showed low sequence specificity, as a mismatch base is located near the terminal of the target sequence. However, PNA13 showed less binding to the mismatched RNA1, as the incubation temperature was increased to $55{ }^{\circ} \mathrm{C}$. In contrast, PNA14 showed reduced binding to the mismatched RNA 1 at $40{ }^{\circ} \mathrm{C}$ and the band shift was drastically reduced at $55^{\circ} \mathrm{C}$. Tolane-modified PNA showed improved sequence specificity, as a mismatch base is located near the terminal of the target sequence, which was probably due to 
selective stacking interactions with only the matched neighboring base pair. These results correspond to the results of their melting temperature analyses that are summarized in Table 7. Regarding the $N$-terminus-modified PNA, a lysine-rich cationic peptide-modified PNA was previously reported to increase the binding constant to a matched DNA by up to 250-fold; however, it also increased the binding constant to mismatched DNA sequences by up to 35-fold relative to that of non-modified PNA [24]. Therefore, tolane-PNA is a better option for discriminating SNPs in a target gene.

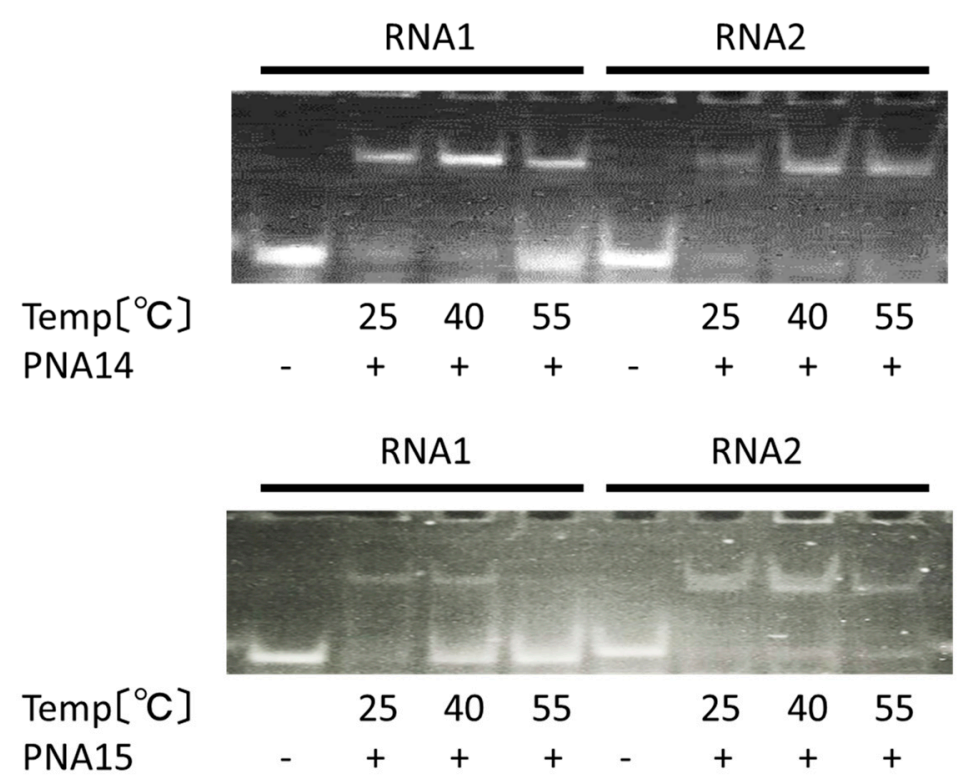

Figure 9. Gel mobility shift assay to assess single nucleotide polymorphism recognition in an RNA oligonucleotide (RNA1, RNA2) by PNA13 and PNA14. RNA1 contains the partial sequence from neuraminidase inhibitor-sensitive influenza A/Yokohama/1/H1N1, while RNA2 contains the partial sequence from the neuraminidase inhibitor-sensitive influenza A/Yokohama/77/H1N1. PNA; 300 nM, RNA; $100 \mathrm{nM}$, incubation; $10 \mathrm{mM}$ phosphate buffer ( $\mathrm{pH}$ 6.0); and, $1 \mathrm{mM}$ EDTA at room temperature for $10 \mathrm{~min}$, gel shift assay; 15\% acrylamide gel, $20 \mathrm{~mA}, 60 \mathrm{~min}$.

Here, we proposed a new PNA chromatography system to detect a SNP related to the neuraminidase-inhibitor susceptibility of the influenza viral gene. We recently reported a PNA-based ELISA system [25] and a rapid diagnostic test kit while using nucleic acid chromatography for discriminating influenza A viruses [26]. In both methods, PNAs target a conserved sequence of a viral gene of influenza A viruses. These PNA recognizes the viral gene in a sequence-specific manner. As the viral RNA forms ribonucleoprotein complexes with nucleoprotein (NP) [27], their PNAs can form a complex with viral RNA/nucleoprotein, or ribonucleoprotein (RNP) within the virus lysate (Figure 10, top A; PNA/RNP formation). This PNA/RNP complex can be visualized by a gold nanoparticle-conjugated rabbit anti-nucleoprotein IgG antibody (gold-rabbit anti-NP IgG) in the control line, and a red color develops as a result of surface plasmon resonance (Figure 10, top B; PNA/RNP detection). In addition, we prepared a control line that can capture gold-rabbit anti-NP IgG by anti-rabbit IgG antibody to confirm the flow of the sample through the device (Figure 10, top C; Confirmation). We employed this system to discriminate a SNP that is involved in neuraminidase inhibitor resistance and neuraminidase inhibitor-sensitive viral strains.

We decided to perform this nucleic acid chromatography detection at $55^{\circ} \mathrm{C}$ to eliminate mismatched binding but to retain matched binding since PNA14 can slightly bind to RNA1 that contains a mismatched base at $40{ }^{\circ} \mathrm{C}$ (Figure 9). First, we added a neuraminidase inhibitor-resistant virus (NIR virus) and neuraminidase inhibitor-sensitive virus (NIS virus) into an elution buffer (see Materials and Methods section). Subsequently, PNA13 or PNA14 was added to the elution mixture and then incubated at $55{ }^{\circ} \mathrm{C}$ for $5 \mathrm{~min}$. The PNA-containing elution mixtures were dropped onto a conjugation 
pad of the PNA chromatography at $55^{\circ} \mathrm{C}$ and let react for $15 \mathrm{~min}$. As a result, PNA13 could not discriminate the SNPs between these two viruses and detected both the NIR and the NIS viruses on the chromatograph (Figure 10, bottom left). By contrast, PNA14 discriminated the SNPs among these viruses and selectively detected the NIR virus, which possesses a complementary viral RNA sequence, on the chromatograph (Figure 10, bottom right). These results correspond to the results of the gel mobility shift assay that is shown in Figure 9. Further, our chromatography system is advantageous when compared to microarray technology, since it does not require the additional steps of target genome amplification, hybridization, washing, and fluorescence detection during the diagnosis process. Our chromatography method is also advantageous when compared to the immunochromatography approach that has been widely used in bedside applications. In particular, the immunochromatography kit requires two antibodies for the detection of a target antigen in a sandwich fashion and, thus, the sensitivity and specificity rely on the quality of these two antibodies. By contrast, PNA chromatography requires a tolane-PNA that recognizes a conserved gene sequence of the target pathogen and an antibody recognizes the nucleoproteins that are associated with the target gene. The design and synthesis of a certain tolane-PNA for detecting a viral or bacterial gene can be accomplished within one week. The development of an antibody targeting an antigen (i.e., nucleoprotein) is easier than developing two antibodies. One of the drawbacks of tolane-PNA chromatography is its low sensitivity (detection limit: $1.0 \times 10^{6} \mathrm{pfu} / \mathrm{mL}$ ). In addition, some binding was lost to the matched binding since a relatively high incubation temperature is required to eliminate the mismatched binding. However, taking these advantages of tolane-PNA together, we could succeed in developing a novel type of nucleic acid chromatography that can effectively discriminate a SNP in influenza A virus.

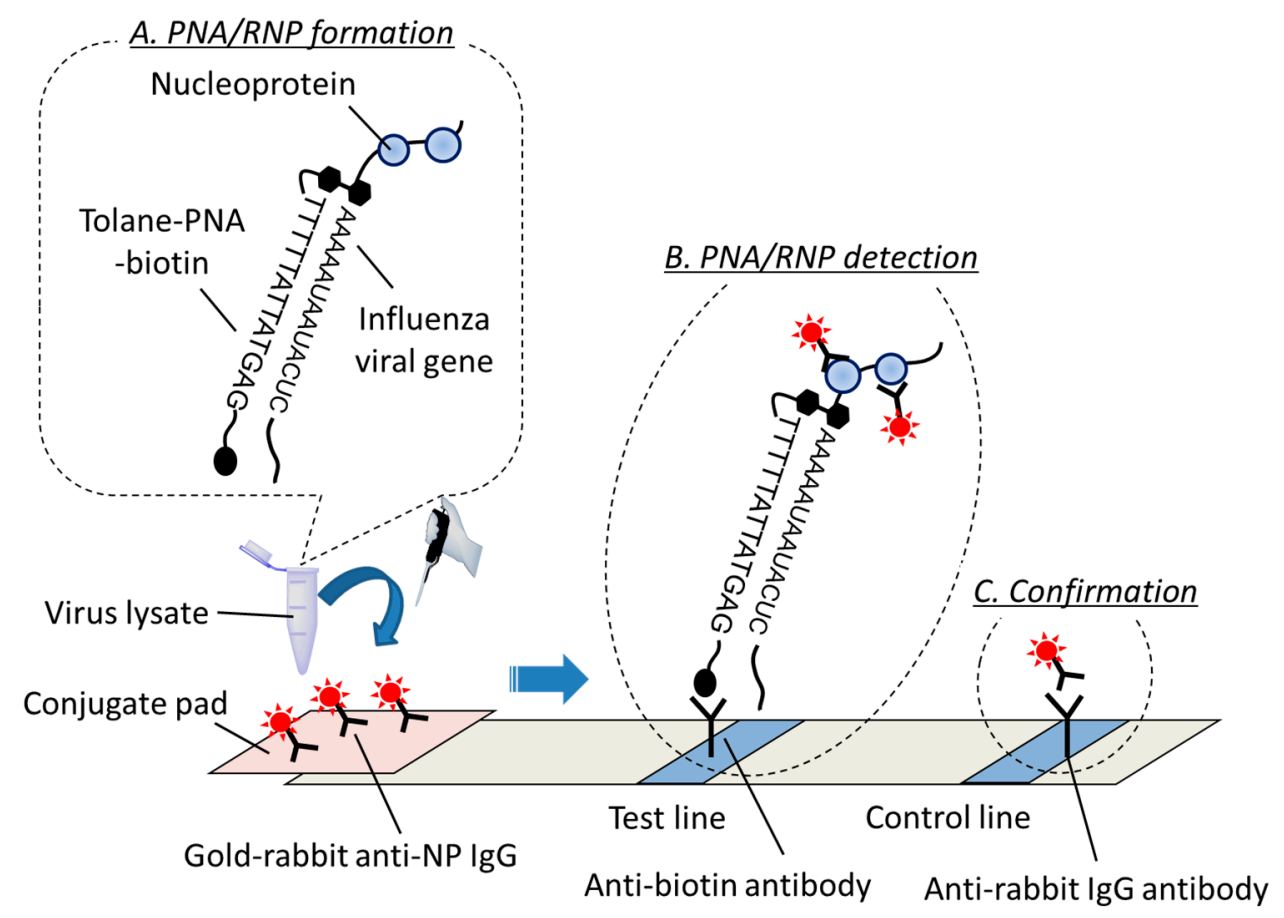

Figure 10. Cont. 


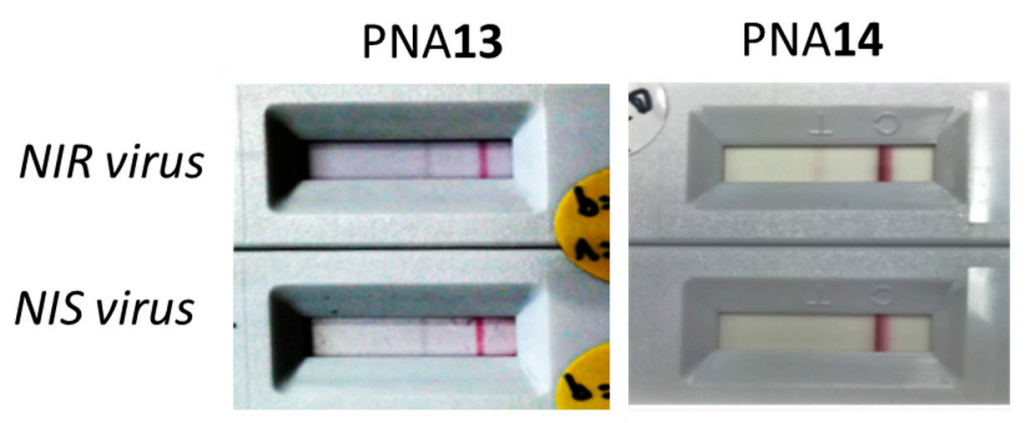

Figure 10. Rapid diagnosis of influenza virus by PNA chromatography. Top) Schematic diagram of the PNA chromatography kit. Top A) PNA/RNP formation, Top B) PNA/RNP detection, Top C) Confirmation. Bottom left) PNA13 did not discriminate a SNP in the target viral RNA among the two viruses and detected both NIR and NIS viruses on the PNA chromatograph. Bottom right) PNA14 discriminated a SNP in the target viral RNA among these two viruses and selectively detected NIR virus on the PNA chromatograph. PNA, $5 \mu \mathrm{L}(0.5 \mu \mathrm{g})$; influenza viruses, $10 \mu \mathrm{L}\left(1.0 \times 10^{6} \mathrm{pfu} / \mathrm{mL}\right)$; elution buffer, $105 \mu \mathrm{L}$ (containing $1 \%$ Tween, $0.5 \%$ BSA). PNA and virus lysate incubation: $55^{\circ} \mathrm{C}, 5 \mathrm{~min}$. Chromatography incubation: $55^{\circ} \mathrm{C}, 15 \mathrm{~min}$.

\section{Materials and Methods}

\subsection{Chemicals for Synthesis of Tolane Derivatives and General Analysis}

All of the reagents and dry solvents were used without any further purification. Silica gel $60 \mathrm{~N}$ (spherical, neutral, particle size 40-50 um, Kanto Chemical Co. Inc., Tokyo, Japan) were used for column chromatography, unless otherwise noted. Thin-layer chromatography was performed while using Merck TLC silica gel 60 F254 (Merck KGaA, Darmstadt, Germany). Nuclear magnetic resonance (NMR) spectrum was recorded on a JEOL JML-LA-400 H1 400MHz (JEOL Ltd., Tokyo, Japan). The spectra were internally referenced to the tetramethylsilane signal at $0 \mathrm{ppm}, \mathrm{CDCl} 3(7.24 \mathrm{ppm})$, and DMF (2.5 ppm). Mass measurements were recorded on JEOL JMS-T100LC (ESI-TOF-HRMS) (JEOL Ltd., Tokyo, Japan).

\subsection{Synthesis of Tolane Derivatives}

The details were written in the supplemental data. Briefly, we prepare the linker molecule with a carboxylic acid one side and 4-bromo-phenyl group the other side. The carboxylic acid was esterified with methanol and 4-bromo-phenyl group was reacted with ethynylbenzene while using the Sonogashira coupling reaction. After the methoxy ester was hydrolysed to carboxylic acid in lithium hydroxide solution. The free carboxylic acid group was used for amide coupling with the N-terminal amino of PNA.

\subsection{Chemicals for PNA Synthesis}

Fmoc/Bhoc-protected PNA monomers were purchased from Panagene (Daejeon, Korea). Fmoc-Lys(Boc)-OH, poly-ethylene linker, and TGR-resin were purchased from Merck Millipore (Tokyo, Japan). The coupling activators and HATU were purchased from Watanabe Chemicals (Hiroshima, Japan). DNA (salt free) was purchased from Sigma-Genosys (Ishikari, Japan). Other chemicals were purchased from Wako Pure Chemical (Osaka, Japan), Sigma-Aldrich (Tokyo, Japan), and Tokyo Chemical Industry (Tokyo, Japan). The reagents and solvents were used without further purification, unless otherwise noted.

\subsection{Preparation of Fmoc-Lys-(Boc)-OH Loaded Resin}

The Novasyn TGR resin $(200 \mathrm{mg}, 0.24 \mathrm{mmol} / \mathrm{g}$ ) was swollen in $5 \mathrm{~mL}$ DMF for $30 \mathrm{~min}$ prior to the synthesis. $200 \mu \mathrm{L}$ of base solution (0.3 M 2,6-lutidine, $0.2 \mathrm{M}$ diisopropyl ethylamine, and $0.33 \mathrm{M}$ thiourea 
solution) and 0.5 M HATU were added to a mixture of Fmoc/Boc-protected lysine (Fmoc-Lys(Boc)-OH, $22.5 \mathrm{mg}, 48 \mu \mathrm{mol}$ ), and Boc/Cbz-protected lysine (Boc-Lys(Cbz)-OH, $72.3 \mathrm{mg}, 190 \mu \mathrm{mol})$ in $200 \mu \mathrm{L}$ of DMF to activate the carboxyl groups of coupling monomers. For the coupling reaction, the mixture was added to the resin and then incubated at ambient temperature for $60 \mathrm{~min}$. The resin was then removed from the reaction solution and washed with DMF $(5 \times 5 \mathrm{~mL})$. For the capping of non-reacted amine groups, the resin was treated with $1.5 \mathrm{~mL}$ of capping solution (2,6-lutidine: $\mathrm{Ac}_{2} \mathrm{O}$ :pyridine = 6:5:89, $v / v)$ for $5 \mathrm{~min}$ and washed with DMF $(10 \times 5 \mathrm{~mL})$. For the deprotection of Fmoc-groups, the resin was treated with $1 \mathrm{~mL}$ of deblock solution $(40 \%(v / v)$ piperidine in DMF) for $5 \mathrm{~min}$ and washed with DMF $(10 \times 5 \mathrm{~mL})$.

\subsection{PNA Synthesis}

Automated linear solid phase synthesis of PNA was performed while using an Intavis ResPep parallel synthesizer that was equipped with micro scale columns (Köln, Germany). The lysine-loaded resin $(200 \mathrm{mg}, 16 \mu \mathrm{mol})$ was swollen in $5 \mathrm{~mL}$ DMF for $30 \mathrm{~min}$, and $20 \mathrm{mg}$ of the resin was transferred to each column in the synthesizer. After the removal of DMF, the Fmoc-protecting groups of the lysine-loaded resin were removed from the resin by a 10-min incubation in $100 \mu \mathrm{L}$ of deblock solution; the resin was subsequently washed with $100 \mu \mathrm{L}$ of DMF 10 times. The concentration of each monomer (Fmoc-PNA monomers, Fmoc-AEEA-OH, Fmoc-AZO-OH, and Fmoc-Lys(Boc)-OH) was adjusted to $0.3 \mathrm{M}$ in DMF solution. The activator solution contained 0.5 M HATU in DMF. The base solution contained 0.3 M 2,6-lutidine, $0.2 \mathrm{M}$ diisopropyl ethylamine, and $0.33 \mathrm{M}$ thiourea in 5\% NMM in pyridine solution $(v / v)$. The deblock solution contained $40 \%$ pyperidine in DMF solution.

For the coupling reaction, $17.5 \mu \mathrm{L}$ of monomer solution, $17.0 \mu \mathrm{L}$ of activation solution, and $8.50 \mu \mathrm{L}$ of base solution were combined in a vessel and incubated for $2 \mathrm{~min}$ at ambient temperature. The coupling solution was then transferred to $20 \mathrm{mg}$ of the resin and then incubated for $100 \mathrm{~min}$ at ambient temperature. After eluting the coupling solution from the resin by filtration, the resin was washed with $100 \mu \mathrm{L}$ of DMF 10 times. This coupling procedure was repeated twice for each monomer elongation reaction. The resin was then incubated with $100 \mu \mathrm{L}$ of capping solution for $10 \mathrm{~min}$. to protect the non-elongated amino groups with acetyl groups and subsequently washed with $100 \mu \mathrm{L}$ of DMF 10 times. The N-terminus Fmoc-group was then removed by incubating the resin with $100 \mu \mathrm{L}$ of deblock solution for 10 min and subsequently washing with $100 \mu \mathrm{L}$ of DMF 10 times. The coupling step of the next monomer and capping steps were repeated, as described above, until the desired PNA molecule was synthesized. Before the cleavage of PNA molecules from the resin, the resin was washed with $100 \mu \mathrm{L}$ of DMF five times, followed by washing with $100 \mu \mathrm{L}$ of dichloromethane five times. After drying the resin, $1 \mathrm{~mL}$ of TFA/m-cresol $(9: 1, v / v)$ was added and incubated for $12 \mathrm{~h}$. The resin was then filtered and the flow-through containing the cleaved PNA was transferred to a new tube. The PNA solution was added to $15 \mathrm{~mL}$ of ice-cold diethyl ether, and the precipitate was collected by centrifugation at $4400 \mathrm{rpm}$ for $4 \mathrm{~min}$. The supernatant was transferred to another tube and then discarded. The residue was dried under ambient atmosphere and then dissolved in $100 \mu \mathrm{L}$ of distilled water.

\subsection{PNA Purification and Analysis}

All of the PNAs were purified by reverse-phase HPLC using a JASCO PU-2086 pump system (Tokyo, Japan) with a JASCO UV-2075 detector and a GL Science Inertsil $(150 \mathrm{~mm} \times 4.6 \mathrm{~mm}, 5 \mu \mathrm{m})$ C-18 column for analytical runs or a GL Science Inertsil $(20 \mathrm{~mm} \times 250 \mathrm{~mm}, 3 \mu \mathrm{m}) \mathrm{C}-18 \mathrm{column}$ for semi-preparative runs. Eluting solvents (analytical: A $(0.1 \%$ TFA in water) and B $(0.1 \%$ TFA in acetonitrile); semi preparative: A (0.1\% TFA in water) and B ( $0.1 \%$ TFA in acetonitrile)) were used in a linear gradient at a flow rate of $1 \mathrm{~mL} / \mathrm{min}$ for analytical and $5 \mathrm{~mL} / \mathrm{min}$ for semi-preparative HPLC. The gradient for analytical runs was $0 \rightarrow 50 \% \mathrm{~B}$ in $30 \mathrm{~min}$, and the gradient for semi-preparative runs was $0 \% \mathrm{~B}$ for $10 \mathrm{~min}, 0 \rightarrow 5 \% \mathrm{~B}$ in $10 \mathrm{~min}, 5 \% \mathrm{~B}$ for $10 \mathrm{~min}, 5 \rightarrow 10 \% \mathrm{~B}$ in $10 \mathrm{~min}, 10 \% \mathrm{~B}$ for $10 \mathrm{~min}, 10 \rightarrow 20 \% \mathrm{~B}$ in $120 \mathrm{~min}$, and $20 \rightarrow 50 \% \mathrm{~B}$ in $10 \mathrm{~min}$. Detection was performed while using a UV-VIS-detector at $260 \mathrm{~nm}$. PNA molecular weights were analysed using an Ultraflextreme MALDI TOF Mass Spectrometer 
(Bruker Daltonics, Yokohama, Japan). The optical densities of PNA and DNA were measured at $260 \mathrm{~nm}$ with a UV1700 spectrometer (Shimadzu, Kyoto, Japan) using quartz cuvettes $(4 \times 10 \mathrm{~mm})$. The extinction coefficient of PNA was calculated from the molar extinction coefficient obtained from http://www.panagene.com/. The molar extinction coefficient of tolane derivatives 1-8, 9, 10, 11, and 12 were $15,600,15,000,16,500,9600$, and 11,000 $\left(\mathrm{M}^{-1} \mathrm{~cm}^{-1}\right)$, respectively. Measurements of absorption at $260 \mathrm{~nm}$ were carried out in a buffer solution $\left(10 \mathrm{mM} \mathrm{NaH} \mathrm{PO}_{4}, \mathrm{pH} 7.0\right)$ at an ambient temperature.

\subsection{UV-Melting Analysis of PNA/DNA and Tolane-PNA/DNA}

PNAs were preheated at $95^{\circ} \mathrm{C}$ for 5 min to prevent aggregation, and then gradually cooled to $25^{\circ} \mathrm{C}$ before being added to the DNA solution. The melting profiles of PNA complexed with DNA or RNA were analysed on a UV1700 spectrophotometer (Shimadzu) while using a microcell (eight cells, $1 \mathrm{~mm}$ ) at $260 \mathrm{~nm}$. PNAs and DNA were suspended in $20 \mathrm{mM}$ sodium phosphate buffer (pH 7.4) at $4 \mu \mathrm{M}$ each. The PNAs and RNA were suspended in $10 \mathrm{mM}$ sodium phosphate buffer and 1mM EDTA ( $\mathrm{pH}$ 6.0) at $4 \mu \mathrm{M}$ each. The temperature was ramped down from $95^{\circ} \mathrm{C}$ to $10^{\circ} \mathrm{C}$ at a rate of $-1{ }^{\circ} \mathrm{C} / \mathrm{min}$.

\subsection{In silico Conformational Search of Tolane Derivatives in the PNA/DNA Duplex}

A PNA/DNA duplex structure that was solved by NMR methodology has been registered in the Protein Data Bank (PDB ID:1PDT). Tolane derivatives were introduced to the N-terminal amino group of PNA via an amide linkage, and an in silico conformational search of tolane within the PNA/DNA duplex was performed by Macromodel version 10.5 (Schrödinger, LLC, New York, NY, 2014). The torsion angle search approach, followed by minimization using an OPLS-2005 force field in water was utilized to analyze the stacking conformers.

\subsection{Analysis of Duplex Conformation of Tolane-PNA/DNA Duplexes by Fluorescence Spectroscopy}

Cy5-labelled DNA concentrations were quantified by absorbance at $260 \mathrm{~nm}$ while using a molar extinction coefficient provided by manufacturer. Fluorescence Spectrophotometer F-7000 identified excitation wavelength and emission wavelengths at $323 \mathrm{~nm}$ and $384 \mathrm{~nm}$. PNA9 were preheated at $95{ }^{\circ} \mathrm{C}$ for $5 \mathrm{~min}$ to prevent aggregation, then gradually cooled to $25^{\circ} \mathrm{C}$ before being added to DNA solutions. PNA9, DNA1, and DNA2 concentrations were quantified by absorbance at $260 \mathrm{~nm}$ while using a molar extinction coefficient that was provided by the manufacturer. Fluorescence spectrum of PNA9 alone, PNA9/DNA1, and PNA9/DNA2 were measured in $20 \mathrm{mM}$ sodium phosphate (pH 7.4) at $25{ }^{\circ} \mathrm{C}$.

\subsection{Gel Mobility Shift Analysis of PNA/RNA Complexes}

PNAs were preheated at $95^{\circ} \mathrm{C}$ for $5 \mathrm{~min}$ to prevent aggregation, and then gradually cooled to $25{ }^{\circ} \mathrm{C}$ before being added to the RNA solution. The RNA concentrations were quantified by absorbance at $260 \mathrm{~nm}$ while using a molar extinction coefficient provided by the manufacturer. PNA/RNA hybridization assays were conducted while using $100 \mathrm{nM}$ Cy5-labeled single strand RNA with $300 \mathrm{nM}$ PNA, or tolane-PNA in $10 \mathrm{mM}$ sodium phosphate and $1 \mathrm{mM}$ EDTA at pH 6.0 for $10 \mathrm{~min}$ at $25^{\circ} \mathrm{C}$. The reaction mixture for each condition was mixed with 0.2 volumes of a solution containing $30 \%$ glycerol, 0.025\% bromophenol blue, and 0.025\% xylencyanol (Sigma-Aldrich Japan, Tokyo, Japan), and then subjected to electrophoresis at $20 \mathrm{~mA}$ for $60 \mathrm{~min}$ on a $15 \%$ non-denaturing polyacrylamide gel using 1x TBE as a running buffer ( $89 \mathrm{mM}$ Tris base, $89 \mathrm{mM}$ borate, $2 \mathrm{mM}$ EDTA, pH 8.1$)$ at $4{ }^{\circ} \mathrm{C}$ in the dark. The gel images were created by the use of a CCD digital image stock system, FAS-III (Toyobo, Osaka, Japan).

\subsection{Preparation of Influenza A/Yokohama/1/2008/H1N1 and A/Yokohama/77/2008/H1N1}

Influenza A/Yokohama/1/2008/H1N virus and A/Yokohama/77/2008/H1N virus were propagated in chicken embryonated eggs and then purified by sucrose gradient ultracentrifugation. For the PNA 
binding assay, the viral titers were assessed while using a plaque formation assay and adjusted to $1.0 \times 10^{6} \mathrm{pfu} / \mathrm{mL}$ with a phosphate buffered saline $(\mathrm{pH} 7.4)$.

\subsection{Discrimination of a SNP in the Neuraminidase Gene of Influenza A Virus by PNA and Tolane-PNA Using Nucleic Acid Chromatography}

The samples containing influenza virus $\left(10 \mu \mathrm{L}\right.$ of $\left.1.0 \times 10^{6} \mathrm{pfu} / \mathrm{mL}\right)$ were added to 105 $\mu \mathrm{L}$ of phosphate buffer $\left(\mathrm{pH}\right.$ 7.4) containing detergents at $55{ }^{\circ} \mathrm{C}$ and dropped to a conjugate pad of the kit. We first formed the complex between tolane-PNA-biotin and influenza viral RNA/nucleoprotein in the sample lysate, which was dropped onto the conjugation pad, and then flowed by chromatography on the membrane towards the test and control lines. PNA-Lys-O-O-Lys(biotin) and tolane-PNA-Lys-O-O-Lys(biotin) was preheated at $95^{\circ} \mathrm{C}$ for $5 \mathrm{~min}$ to prevent aggregation, and then gradually cooled to $55^{\circ} \mathrm{C}$ before being added to the influenza virus detergent. After incubation of $0.5 \mu \mathrm{g}$ of PNA-Lys-O-O-Lys(biotin) and tolane-PNA-Lys-O-O-Lys(biotin) solution with $115 \mu \mathrm{L}$ of the viral lysate at $55^{\circ} \mathrm{C}$ for $5 \mathrm{~min}$, the mixture was dropped onto a conjugate pad on a lateral flow strip that contains a gold-rabbit anti-nucleoprotein at $55^{\circ} \mathrm{C}$ in a $\mathrm{CO}_{2}$ gas incubator SCA series (ASTEC, Fukuoka, Japan). PNAs can form a complex with the influenza viral RNA and the nucleoprotein (RNP) within the virus lysate. This PNA/RNP complex can be visualized by gold-nanoparticle that was conjugated rabbit anti-nucleoprotein IgG antibody (gold-rabbit anti-NP) in the control line, and a red color develops as a result of surface plasmon resonance. In addition, we prepared a control line that can capture the excess gold-rabbit anti-NP by anti-rabbit IgG to confirm the flow of sample through the device. We employed this system to discriminate a SNP in neuraminidase inhibitor-resistant and neuraminidase inhibitor-sensitive viral strains.

\section{Conclusions}

We designed and synthesized various types of tolane derivatives that possess different types of linkers, such as alkyl linkers, ether linkers, and amide linkers. These were incorporated at the $\mathrm{N}$-terminus of the PNA to increase its sequence specificity against ssDNA. As a result, we found that the best linker length among the different alkyl acids tested was pentanoic acid. The substitution of pentanoic acid with ethoxypropanoic acid further increased the binding affinity of the tolane-PNA due to its flexible structure. Extension of the pi-conjugated system by changing from a phenyl to naphthyl group also increased the binding affinity to neighboring base pairs and increased duplex stability in a sequence specific manner. We were able to discriminate a single base mismatch in the terminal region of target DNA and RNA molecules without increasing the binding to mismatched genes to activate the carboxyl groups of coupling monomers. A novel type of nucleic acid chromatography that employed our tolane-modified PNA allowed for us to detect a SNP related to drug-resistance found in an influenza virus without using PCR-based genome amplification reaction. Therefore, tolane-modified PNA chromatography has the potential to directly enable the simple diagnosis of drug-resistant viruses from viral samples at the bedside without requiring PCR, gel electrophoresis, mass spectroscopy, or fluorescence detection.

Supplementary Materials: The following are available online, Figure S1: Conformational search of tolane4-PNA/DNA duplex.

Author Contributions: Conceptualization, K.T., T.H., S.S., and M.O.; methodology, K.T., T.H., S.S., and M.O.; software, K.T.; validation, K.T., S.H., and K.O.; formal analysis, K.T., T.H., and M.O.; investigation, K.T., T.H., S.S., and M.O.; resources, N.K., Y.E., and K.K.; data curation, K.T., T.H., S.S., M.O., S.H., and K.O.; writing-original draft preparation, K.K.; writing-review and editing, Y.E.; visualization, K.T., and K.K.; supervision, N.K.; project administration, N.K. and K.K.; funding acquisition, N.K., Y.E., and K.K. All authors have read and agreed to the published version of the manuscript.

Funding: This work was supported by a Grant-in-Aid for Young Scientists (B) (22750155 to KK) from JSPS and a Grant-in-Aid for Scientific Research (B) (25290073 to KK) from JSPS.

Acknowledgments: We thank Aya Takenaka and Hiroyo Matsumura for their kind assistance to this work. 
Conflicts of Interest: The authors declare no conflict of interest. The funders had no role in the design of the study; in the collection, analyses, or interpretation of data; in the writing of the manuscript, or in the decision to publish the results.

\section{References}

1. Scitable. Definition, SNP. Available online: https://www.nature.com/scitable/definition/snp-295/ (accessed on 10 February 2020).

2. Li, J.Z.; Paredes, R.; Ribaudo, H.J.; Svarovskaia, E.S.; Metzner, K.J.; Kozal, M.J.; Hullsiek, K.H.; Balduin, M.; Jakobsen, M.R.; Geretti, A.M.; et al. Low-frequency HIV-1 drug resistance mutations and risk of NNRTI-based antiretroviral treatment failure: A systematic review and pooled analysis. JAMA 2011, 305, 1327-1335. [CrossRef] [PubMed]

3. Suzuki, Y.; Saito, R.; Sato, I.; Zaraket, H.; Nishikawa, M.; Tamura, T.; Dapat, C.; Caperig-Dapat, I.; Baranovich, T.; Suzuki, T.; et al. Identification of Oseltamivir Resistance among Pandemic and Seasonal Influenza A (H1N1) Viruses by an His275Tyr Genotyping Assay Using the Cycling Probe Method. J. Clin. Microbiol. 2011, 49, 125-130. [CrossRef] [PubMed]

4. Nielsen, P.; Egholm, M.; Berg, R.; Buchardt, O. Sequence-selective recognition of DNA by strand displacement with a thymine-substituted polyamide. Science 1991, 254, 1497-1500. [CrossRef] [PubMed]

5. Hanvey, J.; Peffer, N.; Bisi, J.; Thomson, S.; Cadilla, R.; Josey, J.; Ricca, D.; Hassman, C.; Bonham, M.; Au, K.; et al. Antisense and antigene properties of peptide nucleic acids. Science 1992, 258, 1481-1485. [CrossRef]

6. Larsen, H.; Bentin, T.; Nielsen, P.E. Antisense properties of peptide nucleic acid. Biochim. Biophys. Acta (BBA)—Gene Struct. Expr. 1999, 1489, 159-166. [CrossRef]

7. Ray, A.; Nordén, B. Peptide nucleic acid (PNA): Its medical and biotechnical applications and promise for the future. FASEB J. 2000, 14, 1041-1060. [CrossRef]

8. Egholm, M.; Buchardt, O.; Christensen, L.; Behrens, C.; Freier, S.M.; Driver, D.A.; Berg, R.H.; Kim, S.K.; Nordén, B.; Nielsen, P.E. PNA hybridizes to complementary oligonucleotides obeying the Watson-Crick hydrogen-bonding rules. Nature 1993, 365, 566-568. [CrossRef]

9. Demidov, V.V.; Potaman, V.N.; Frank-Kamenetskil, M.; Egholm, M.; Buchard, O.; Sönnichsen, S.H.; Nlelsen, P.E. Stability of peptide nucleic acids in human serum and cellular extracts. Biochem. Pharmacol. 1994, 48, 1310-1313. [CrossRef]

10. Hamilton, S.E.; Iyer, M.; Norton, J.C.; Corey, D.R. Specific and nonspecific inhibition of transcription by DNA, PNA, and phosphorothioate promoter analog duplexes. Bioorganic Med. Chem. Lett. 1996, 6, 2897-2900. [CrossRef]

11. Ross, P.L.; Lee, K.; Belgrader, P. Discrimination of single-nucleotide polymorphisms in human DNA using peptide nucleic acid probes detected by MALDI-TOF mass spectrometry. Anal. Chem. 1997, 69, 4197-4202. [CrossRef]

12. Ren, B.; Zhou, J.-M.; Komiyama, M. Straightforward detection of SNPs in double-stranded DNA by using exonuclease III/nuclease S1/PNA system. Nucleic Acids Res. 2004, 32, e42. [CrossRef] [PubMed]

13. Boontha, B.; Nakkuntod, J.; Hirankarn, N.; Chaumpluk, P.; Vilaivan, T. Multiplex Mass Spectrometric Genotyping of Single Nucleotide Polymorphisms Employing Pyrrolidinyl Peptide Nucleic Acid in Combination with Ion-Exchange Capture. Anal. Chem. 2008, 80, 8178-8186. [CrossRef] [PubMed]

14. Gaylord, B.S.; Massie, M.R.; Feinstein, S.C.; Bazan, G.C. SNP detection using peptide nucleic acid probes and conjugated polymers: Applications in neurodegenerative disease identification. Proc. Natl. Acad. Sci. USA 2005, 102, 34-39. [CrossRef] [PubMed]

15. Rockenbauer, E.; Petersen, K.; Vogel, U.; Bolund, L.; Kølvraa, S.; Nielsen, K.V.; Nexø, B.A. SNP genotyping using microsphere-linked PNA and flow cytometric detection. Cytom. Part. A 2005, 64, 80-86. [CrossRef]

16. Bethge, L.; Jarikote, D.V.; Seitz, O. New cyanine dyes as base surrogates in PNA: Forced intercalation probes (FIT-probes) for homogeneous SNP detection. Bioorganic Med. Chem. 2008, 16, 114-125. [CrossRef]

17. Socher, E.; Jarikote, D.V.; Knoll, A.; Röglin, L.; Burmeister, J.; Seitz, O. FIT probes: Peptide nucleic acid probes with a fluorescent base surrogate enable real-time DNA quantification and single nucleotide polymorphism discovery. Anal. Biochem. 2008, 375, 318-330. [CrossRef] 
18. Ditmangklo, B.; Taechalertpaisarn, J.; Siriwong, K.; Vilaivan, T. Clickable styryl dyes for fluorescence labeling of pyrrolidinyl PNA probes for the detection of base mutations in DNA. Org. Biomol. Chem. 2019, 17, 9712-9725. [CrossRef]

19. Kam, Y.; Rubinstein, A.; Nissan, A.; Halle, D.; Yavin, E. Detection of Endogenous K-ras mRNA in Living Cells at a Single Base Resolution by a PNA Molecular Beacon. Mol. Pharm. 2012, 9, 685-693. [CrossRef]

20. Kolevzon, N.; Hashoul, D.; Naik, S.; Rubinstein, A.; Yavin, E. Single point mutation detection in living cancer cells by far-red emitting PNA-FIT probes. Chem. Commun. 2016, 52, 2405-2407. [CrossRef]

21. Sawada, S.; Takao, T.; Kato, N.; Kaihatsu, K. Design of Tail-Clamp Peptide Nucleic Acid Tethered with Azobenzene Linker for Sequence-Specific Detection of Homopurine DNA. Molecules 2017, 22, 1840. [CrossRef]

22. Dogan, Z.; Paulini, R.; Stütz, J.A.R.; Narayanan, S.; Richert, C. 5'-Tethered Stilbene Derivatives as Fidelityand Affinity-Enhancing Modulators of DNA Duplex Stability. J. Am. Chem. Soc. 2004, 126, 4762-4763. [CrossRef] [PubMed]

23. Kawakami, C.; Obuchi, M.; Saikusa, M.; Noguchi, Y.; Ujike, M.; Odagiri, T.; Iwata, M.; Toyozawa, T.; Tashiro, M. Isolation of oseltamivir-resistant influenza A/H1N1 virus of different origins in Yokohama City, Japan, during the 2007-2008 influenza season. Jpn. J. Infect. Dis. 2009, 62, 83-86. [PubMed]

24. Kaihatsu, K.; Shah, R.H.; Zhao, X.; Corey, D.R. Extending Recognition by Peptide Nucleic Acids (PNAs): Binding to Duplex DNA and Inhibition of Transcription by Tail-Clamp PNA-Peptide Conjugates + . Biochemistry 2003, 42, 13996-14003. [CrossRef] [PubMed]

25. Kaihatsu, K.; Sawada, S.; Nakamura, S.; Nakaya, T.; Yasunaga, T.; Kato, N. Sequence-Specific and Visual Identification of the Influenza Virus NS Gene by Azobenzene-Tethered Bis-Peptide Nucleic Acid. PLoS ONE 2013, 8, e64017. [CrossRef] [PubMed]

26. Kaihatsu, K.; Sawada, S.; Kato, N. Rapid Identification of Swine-Origin Influenza A Virus by Peptide Nucleic Acid Chromatography. J. Antivirals Antiretrovir. 2013, 5, 77-79.

27. Kemler, I.; Whittaker, G.; Helenius, A. Nuclear Import of Microinjected Influenza Virus Ribonucleoproteins. Virology 1994, 202, 1028-1033. [CrossRef]

Sample Availability: Samples of the compounds are not available from the authors.

(C) 2020 by the authors. Licensee MDPI, Basel, Switzerland. This article is an open access article distributed under the terms and conditions of the Creative Commons Attribution (CC BY) license (http://creativecommons.org/licenses/by/4.0/). 